\title{
Do Proprietary Costs Deter Insider Trading?
}

\section{Introduction}

Insider trading is an important mechanism through which insiders' private information gets impounded into stock prices (Aboody and Lev 2000; Brochet 2010; Choi et al. 2019; Damodaran and Liu 1993; Lakonishok and Lee 2001; Meulbroek 1992). Prior research extensively explores the determinants and consequences of insider trading, largely focusing on its capital market implications. Concurrently, the voluntary disclosure literature focuses on the capital market benefits and product market costs of disclosure (e.g., Verrecchia 1983, 2001; Dye 1986; Brown et al. 2004; Li 2010; Ali et al. 2014). One of the primary reasons why firms do not fully disclose their private information is because disclosures reveal proprietary information to rivals, who might use it to compete more effectively against disclosing firms. In this paper, we postulate that insider trading not only conveys insiders' private information to capital market participants, but also to rival firms. As such, a potential, yet previously unanalyzed cost of insider trading is its ability to harm the competitive position of insiders' firms. Thus, we conjecture insiders at high proprietary cost firms limit their trading to avoid undermining their firms' positions in the product market.

Although insider trading does not directly provide detailed proprietary information, such as the current status of a drug trial, it conveys insiders' views on the firm's prospects. If, albeit noisy, inferences can be drawn from insiders' trades, such information could prove valuable for rivals in devising product or marketing strategies. Competitors do not need to rely solely on the insider purchases, per se, to make inferences about the disclosing firms and/or the competitive landscape. Instead, the trading signal may spur rivals to increase or focus their competitive intelligence efforts on the disclosing firms more than they otherwise would, and base their strategic 
responses on the additional information they acquire. ${ }^{1}$ Such information transfers would be especially costly for firms that are more vulnerable to competitors' actions. In such an environment, reasonable inferences by competitors, such as the likely success of $R \& D$ investments or the progress of product development (e.g., Food and Drug Administration approval or clinical trials), may enable them to make more effective and/or earlier strategic adjustments.

To investigate the link between proprietary costs and insider trading, we first examine whether insiders make fewer purchases at firms with higher proprietary costs. We focus on insider purchases for two reasons. First, insider purchases are more likely to be based on, and hence, convey private information compared to insider sells. Second, insider purchases are less likely to entail litigation and regulatory costs. The latter aspect helps eliminate a potential alternative explanation for our results whereby insiders in firms with high proprietary costs reduce their trading due to litigation concerns. ${ }^{2}$ We capture the extent of insider purchases using the total number of shares purchased by insiders during the year, scaled by the total number of shares outstanding at the beginning of the year. ${ }^{3}$ Since proprietary costs are not directly observable, we employ several variables to proxy for them. Specifically, we use R\&D intensity and patent applications (King et al. 1990), along with product similarity (Hoberg and Phillips 2016), technological similarity (Bloom et al. 2013), competition-related words in 10-Ks (Li et al. 2013),

\footnotetext{
${ }^{1}$ Consistent with this idea, Chen et al. (2018) find evidence suggesting that insider trading disclosures are an important source of information for active fund managers. Indeed, they assert that "insider trades are likely amongst the most valuable [information signals] for unlocking a ... comparative advantage for a given fund manager." Furthermore, their evidence suggest trade disclosures prompt fund managers to investigate the insider's firm more closely in an effort to discover the private information the trade was based on. We expect product market rivals could react in a similar fashion.

${ }^{2}$ Specifically, it could be that higher proprietary costs are associated with higher litigation risk, and it is litigation risk that limits insider purchases, not proprietary cost considerations. However, there are several reasons limiting the plausibility of this alternative explanation. We discuss these arguments and provide additional supporting empirical evidence in Appendix B.

${ }^{3}$ As discussed below, we also consider three alternative measures of insider purchases. We obtain qualitatively similar results using each alternative measure and our inferences remain unchanged.
} 
as well as a composite measure, as proxies for proprietary costs.

The results of our empirical analyses are consistent with our hypothesis. We find there is a strong, negative association between insider purchases and each measure of proprietary costs. These negative associations are economically significant. For example, a one standard deviation increase in the composite measure of proprietary costs is associated with a $10.39 \%$ decrease in insider purchases. Additional cross-sectional analyses show the strength of the negative association increases when we expect insider trading signals are more informative to competitors. Specifically, the negative association between insider purchases and proprietary costs is stronger for opportunistic trades versus routine trades (Cohen et al. 2012), for top executives versus other insiders (Peress 2010; Cheng et al. 2016), low-complexity firms versus high-complexity firms (Frankel et al. 2006), small firms versus large firms (Bernard 2016), and firms with high media coverage versus low media coverage firms (Dai et al. 2015). Overall, the results are consistent with insiders taking proprietary costs into account when making their trading decisions.

Next, we investigate the trade profitability for insiders who trade despite the presence of high proprietary costs. Insiders face a trade-off between their own financial benefits and their firms' proprietary costs. For insiders to trade, the expected benefits must be greater than the associated costs. Thus, when insiders at high proprietary cost firms decide to trade, we hypothesize they earn relatively higher profits in order to offset the additional proprietary costs associated with the trades. The results are consistent with our hypothesis: insider purchase profitability is positively associated with proprietary costs. A one standard deviation increase in the composite proprietary cost measure is associated with a $3.67 \%$ increase in annual abnormal stock returns. Overall, these findings indicate that while insiders engage in fewer purchases when proprietary costs are higher, these trades are more likely to be based on (more) valuable private information. 
We further examine the negative association between proprietary costs and insider purchases by implementing two alternative identification strategies. Specifically, to help alleviate concerns that unobservable and time-varying firm characteristics drive this negative association, we examine two distinct events for which proprietary information risk is expected to be heightened. These analyses enable us to exploit event-driven variation in proprietary costs. First, we analyze insider purchases in the context of new product launches. We expect proprietary information risk is especially high prior to new product announcements. We find insiders significantly reduce their purchases during these proprietary periods relative to other periods, consistent with proprietary concerns discouraging insider trading.

Second, we investigate large reductions in industry-specific U.S. import tariff rates as a source of exogenous shocks increasing proprietary costs. Using a difference-in-differences research design, we examine whether insiders reduce their insider purchases following large tariff reductions in their industries relative to insiders in industries that do not experience such a shock. The results show that relative to firms in unaffected industries, insiders at firms in tariff cut industries significantly reduce their insider purchases. As discussed below, the evidence from tariff reductions reduces, but does not entirely eliminate, concerns about correlated omitted variables. Nevertheless, the results further support our hypothesis of a negative relation between proprietary costs and insider purchases.

Our analyses thus far indicate proprietary costs are negatively associated with insider purchases, but we have not considered specific mechanisms driving this relation. While financial gains from insider trading solely accrue to insiders, the costs of revealing proprietary information are borne by shareholders. We examine two potential reasons why insiders may take proprietary costs into consideration when making their trading decisions. First, when firms have high 
proprietary costs, they may put in place or more strictly enforce existing insider trading restrictions to prevent information leakage. Many firms employ event-specific "blackout" periods such as prior to announcements of new products, clinical trials, or mergers and acquisitions, in addition to quarterly blackout periods around earnings announcements (Bettis et al. 2000; Roulstone 2003). We find firms are more likely to employ insider trading restrictions and/or more likely to enforce existing blackout policies when proprietary costs are higher. Second, insiders may voluntarily refrain from trading if their incentives are more closely aligned with those of shareholders. Our results show the negative association between proprietary costs and insider purchases is significantly stronger when insiders have larger ownership stakes.

This study contributes to two strands of literature. First, this paper adds to the literature on the determinants of insider trading. Prior studies show managers engage in insider trading to exploit private information (Ke et al. 2003; Piotroski and Roulstone 2005; Dechow et al. 2016) and diversify personal wealth (Kallunki et al. 2009), but avoid insider trading to reduce personal tax burdens (Jin and Kothari 2008) and legal risk (Cheng et al. 2016). We find product market considerations are also an important determinant of both insiders' purchase decisions and trading profitability. These findings are likely to be of interest to regulators and corporate boards in setting insider trading policies, and help investors better interpret insider trading signals.

Second, this paper contributes to the literature on the proprietary costs of disclosure. Voluntary disclosure studies show proprietary costs are an important reason for non-disclosure. We view insider trading from the perspective of information disclosure and provide the first empirical evidence on insiders' strategic trading decisions in the presence of proprietary costs. This paper complements prior studies showing firms avoid disclosures about future earnings, 
profitable segments, identity of customers, and financial constraints to maintain their competitive advantage (Botosan and Stanford 2005; Ellis et al. 2012; Bernard 2016; Huang et al. 2017).

Our study's conclusions rely on the assumption that rival firms use the private information conveyed by insider purchases to undermine the firms' competitive positions in some manner (or at least that insiders act as if they do). Similar to numerous papers in the voluntary disclosure literature, we do not nor are we able to provide direct evidence on this channel. Instead, we rely on the documented associations between proprietary costs and insider purchases, as well as our supplementary tests, to infer the existence of this channel.

\section{Prior Literature and Hypothesis Development}

Prior research shows insiders frequently take advantage of their private information when they make their trading decisions. For instance, Ke et al. (2003) examine insider trading patterns prior to a break in quarterly earnings increases. Similarly, Piotroski and Roulstone (2005) document the ratio of insider purchases to total insider trades is positively associated with the firm's future earnings performance. Other studies have found insiders appear to trade on private information about relatively infrequent corporate events such as mergers and acquisitions, Chapter 11 bankruptcy filings, stock repurchases, dividend initiations, earnings restatements, and Securities and Exchange Commission ("SEC") comment letters. Furthermore, prior literature shows that insiders, on average, earn positive abnormal profits on their trades (e.g., Seyhun 1986; Lakonishok and Lee 2001; Ravina and Sapienza 2010), which provides further evidence that insiders frequently trade on private information.

Information about insider trading is disseminated to capital markets through various channels. The SEC requires insiders to report their trading activities on Form 4 filings within two 
business days of the transaction dates. ${ }^{4}$ As of June 30, 2003, the SEC also mandates electronic filings through the EDGAR system. Chen et al. (2018) find that Form 4 filings are the most frequently downloaded form by institutional investors. In addition, various newspapers, business magazines, and websites disseminate insider trading reports obtained from the SEC, which enables outsiders to easily access information about insider trading activities (Dai et al. 2015). ${ }^{5}$

Prior studies indicate investors and other capital market participants are aware that insiders trade on private information and react accordingly (see Bhattacharya 2014 for a review). For example, Brochet (2010) finds significantly positive abnormal returns around the fillings of insider purchases in both the pre-SOX and post-SOX periods. Sivakumar and Vijayakumar (2001) investigate analysts' revision of earnings forecasts following insider trading, and document analysts revise earnings upward following insider purchases. Together, prior research indicates insider trading serves as a valuable source of private information to the capital markets, and market participants react to the information contained in insider trading.

In addition to capital market participants, the information conveyed by insider trades can also be inferred by rivals. We expect competitors find this source of information to be particularly relevant for two reasons. First, insider trading contains firm-specific information. Other sources of information, such as analyst reports, often convey industry-specific or macroeconomic information (Piotroski and Roulstone 2004), for which competitors already have access to. Second, insider trading signals are credible because they involve insiders' personal wealth, unlike management forecasts that are subject to "cheap talk" considerations (Stocken 2000).

\footnotetext{
${ }^{4}$ Before August 29, 2002, insiders were required to file Form 4s to the SEC within ten days after the end of the months in which the trades took place.

${ }^{5}$ The Wall Street Journal provides detailed information and analyses of insider trading activities via the "Insider Trading Spotlight" section on a daily basis. Moreover, numerous websites are dedicated to collect insider trading activities from SEC filings (for example ww.secform4.com and www.insiderslab.com).
} 
Signaling private information to competitors represents a potential cost to the insider's firm because rivals can use the information to disadvantage the insider's firm in the product market. Although insider trading does not provide detailed proprietary information, such as a proprietary formula of a drug, it can signal private information about the firm's financial status, expected sales growth, and likely outcomes of its investment projects. Especially in environments where firms are more vulnerable to competitors' actions, private and forward-looking information about the firm enables competitors to set their product and marketing strategies more effectively. For instance, intensive insider purchases before a product launch may signal a positive outlook for the new product, and hence, may induce a potential competitor to develop a competing product. These signals may also induce rivals to change their production schedules or mimic successful business strategies (e.g., Botosan and Stanford 2005).

To the extent insider trading negatively affects their firms' competitive positions, insiders need to consider potential proprietary costs when making their trading decisions. In a similar vein, the voluntary disclosure literature (e.g., Verrecchia 1983, 2001; Dye 1986) argues proprietary costs prevent firms from fully disclosing all their private information so it will not be revealed to rivals. Consistent with this argument, Verrecchia and Weber (2006) find firms in more concentrated industries are less likely to redact information. Ellis et al. (2012) find firms with higher proprietary costs are more likely to conceal the identities of major customers. More recently, Huang et al. (2017) show product market competition is negatively associated with management earnings forecasts. Their results are consistent with competition reducing voluntary disclosure through higher proprietary costs. Similarly, Bernard (2016) finds financially constrained private firms in Germany reduce financial statement disclosures to mitigate the risk of product market predation.

Graham et al. (2005) find three-fifths of surveyed CFOs agree that proprietary concerns 
are an important barrier to voluntary disclosure. Graham et al. (2005) note "CFOs do not want to explicitly reveal sensitive proprietary information 'on a platter' to competitors, even if such information could be partially inferred from other sources." Thus, similar to managers withholding earnings forecasts to avoid proprietary costs (Bamber and Cheon 1998; Ali et al. 2014; Huang et al. 2017), we expect insiders in firms with high proprietary costs have incentives to abstain from trading to avoid revealing proprietary information. Thus, we make the following hypothesis:

HYPOTHESIS 1: Insider purchases are negatively associated with proprietary costs.

Insiders weigh the expected costs and benefits when they make trading decisions. While insiders obtain financial gains from trading, doing so entails proprietary costs in addition to costs related to litigation or regulatory actions. For insiders to be willing to trade, the expected benefits must exceed the expected costs. Therefore, the expected trading profits must be higher for insiders at high proprietary cost firms in order to offset the higher associated costs incurred when trading at such firms. Thus, we expect that when insiders at high proprietary cost firms decide to trade, they earn higher profits than insiders at low proprietary cost firms. Thus, we hypothesize:

HypothesIS 2: Conditional on an insider trading, the profitability of insider trades is positively associated with proprietary costs.

While the financial benefits from insider trading accrue to insiders, the associated proprietary costs are incurred by shareholders. There are potentially two reasons why insiders reduce trading activities in the face of high proprietary costs. First, firms with high proprietary costs may impose new insider trading restrictions or more strictly enforce existing policies in order to prevent costly information leakage. For instance, many firms employ event-specific blackout periods such as prior to announcements of new products, clinical trials, or mergers and acquisitions in conjunction with quarterly blackout periods around earnings announcements. Second, insiders 
may voluntarily refrain from trading if the associated proprietary costs are sufficiently internalized by insiders through their equity holdings. In which case, we expect insiders voluntarily reduce their trading activities in the face of high proprietary costs to a greater extent when their equity holdings are higher. Accordingly, we hypothesize:

HyPOTHESIS 3A: The likelihood of imposing new, or more strictly enforcing existing, insider trading restrictions is positively associated with proprietary costs.

HYPOTHESIS 3B: The negative association between proprietary costs and insider purchases is stronger for firms in which insiders have higher share ownership.

\section{Sample and Variable Measurement}

\subsection{Sample Selection}

We obtain insider trading data from Thomson Reuters Insider Filings database, which provides transactions by corporate insiders who are subject to disclosure requirements under Section 16 of the Securities Exchange Act of 1934. We include open market stock purchases made by insiders, and thus, exclude stock option exercises. Following prior literature on insider trading (Peress 2010; Cheng et al. 2016), we focus on the top five executives (CEO, CFO, COO, President, and Chairman of Board), as they are the most likely to possess proprietary information, and are more likely to be sensitive to proprietary costs associated with information leakage. We eliminate transactions with a low level of accuracy and reasonableness, transactions completed outside of the open market, and transactions with missing numbers of shares traded. ${ }^{6}$

We obtain financial data from Compustat, stock returns data from CRSP, analyst forecast data from $\mathrm{I} / \mathrm{B} / \mathrm{E} / \mathrm{S}$, institutional ownership and executive share ownership data from Thomson Reuters, and news coverage information from RavenPack News Analytics. In addition, we gather

\footnotetext{
${ }^{6}$ Following Dai et al. (2015), we eliminate transactions with Cleanse codes of "A" or "S," which indicate Thomson Reuters has a low level of confidence regarding the accuracy of the record. Cleanse code " $A$ " indicates that numerous data elements were missing or invalid, and " $\mathrm{S}$ " indicates that the security does not meet the collection requirements.
} 
data on product announcements from S\&P Capital IQ. Finally, we obtain patent data from Noah Stoffman's website, product similarity measures from the Hoberg-Phillips Data Library, and U.S. import data from Peter Schott's website. ${ }^{7}$

We employ two samples in our tests: i) a sample of firm-years for our primary analyses to examine the association between proprietary costs and insider purchases, and ii) a sample of insider purchases for analyses related to the association between proprietary costs and insider trading profits. Because the data availability differs across tests, the sample period and sample size vary for each test. When R\&D is used as a measure of proprietary costs, the sample period is from 1986 to 2017. When the number of patent applications filed and technological similarity are used, the sample period is from 1986 to 2011 . When product similarity (competition-related words) is used, the sample period is from 1997 to 2016 (1995 to 2017). The composite measure is based on R\&D, patent applications, and product similarity to preserve sample size. Hence, the sample is from 1997 to 2011 for this composite measure. Finally, when we use import tariff reductions as exogenous shocks to proprietary costs, the sample is from 1990 to 2017.

Table 1 summarizes the sample selection procedures. Using the composite measure, the final sample of firm-year observations consist of 63,416 firm-years (9,127 distinct firms). The final sample of insider purchases includes 108,790 purchases occurring at 5,724 distinct firms.

\subsection{Measures of Proprietary Costs}

Proprietary costs represent the reduction in firm value resulting from insiders' private information being conveyed by their trading activities. Since proprietary costs are not directly observable, we proxy for these costs using several time-varying firm characteristics. King et al. (1990) argue property rights associated with innovations and intangible assets are not perfectly

\footnotetext{
${ }^{7}$ https://iu.app.box.com/v/patents, http://hobergphillips.usc.edu, http://faculty.som.yale.edu/peterschott, respectively.
} 
enforceable and, hence, are a primary source of proprietary costs. Thus, they suggest several empirical measures of proprietary costs, including the intensity of R\&D expenditures, the number of patents, and various measures of product market competition. ${ }^{8}$

The first proprietary cost measure is $R \& D$ intensity because $R \& D$ activities stimulate product innovation and technological change. Thus, a firm's R\&D resource allocation represents how active the firm is with respect to innovative activities, which arguably carry significant amounts of proprietary information. Consequently, firms with higher R\&D expenditures tend to face higher proprietary costs (Wang 2007; Ellis et al. 2012; Albring et al. 2016). We measure R\&D intensity, $R \& D$, as the decile ranking of $\mathrm{R} \& \mathrm{D}$ expenditures divided by total sales. ${ }^{9}$

Our second proprietary cost measure is the number of patent applications filed in a given year. Firms with more patent filings likely possess higher degrees of confidentiality, and thus, face higher proprietary costs. This measure is widely used in the economics, finance, and accounting literatures to capture innovation (Aghion et al. 2005; He and Tian 2013). We do not use the number of patent citations because our intent is to capture the extent, rather than the quality, of innovative activities. We use patent filings rather than registrations as the former is superior in capturing the creation of the patent and, thus, the time of innovation (e.g, Griliches et al. 1987; He and Tian 2013; Chang et al. 2015). Patents is the natural logarithm of one plus the number of patent applications filed due to the skewness of the data.

\footnotetext{
${ }^{8}$ Industry concentration has been used in prior studies as a measure of product market competition. However, certain studies argue high industry concentration reflects industries with fewer firms, and thus, lower competition among existing rivals (e.g., Li 2010; Li et al 2013), while other studies argue high industry concentration reflects more intense competition among existing rivals (e.g., Raith 2003; Ali et al. 2014). Given these mixed arguments and the related mixed findings, we decide to not include industry concentration as one of our measures of proprietary costs.

${ }^{9}$ Observations with missing or zero R\&D expenditures represent $61 \%$ of all observations. Accordingly, we employ decile rankings, and assign a zero rank to missing and zero R\&D expenditures. Our results are qualitatively similar and our inferences remain unchanged if we i) redefine $R \& D$ after excluding missing and zero R\&D expenditures, and ii) scale $R \& D$ expenditures by total expenses, total assets, or average total assets.
} 
The next proprietary cost measures (Product Similarity, Tech Similarity, and Competition Words) are firm-level measures of product market competition in order to directly capture competition from existing rivals. We expect the proprietary costs of insider trades increase with the amount of product market competition. Product Similarity is developed by Hoberg and Phillips (2016) who construct a text-based measure of product similarity using product descriptions in 10K filings. They calculate firm-by-firm pairwise similarity scores to quantify product similarity between two firms. Product Similarity for firm $i$ is calculated as the sum of the pairwise similarities between firm $i$ and all other Compustat firms in the year. The more similar are firm $i$ 's products to its peers, the more substitutable they are, and hence, the greater the competitive pressure firm $i$ faces. Tech Similarity is developed by Jaffe (1986) and Bloom et al. (2013) based on firm-by-firm pairwise technological similarity scores, which are estimated using the cosine similarity of patent technology classes (426 different classes). The technological similarity measure for firm $i$ is the sum of the pairwise technological similarities between firm $i$ and all other firms in Compustat for the sample period. Following Bloom et al. (2013), we take the natural logarithm of the sum of the pairwise technological similarities scores. Similar to Product Similarity, the more similar are firm $i$ 's technologies to its peers, the more substitutable is firm $i$, and the greater the competitive pressures faced by the firm. Competition Words is from Li et al. (2013) and equals the number of competition-related words (e.g., "competition," "competitor," "competitive," "compete," and "competing") scaled by the total number of words in 10-K filings.

Finally, since each measure captures different dimensions of proprietary costs and are not equally applicable to all firms, we construct a composite measure, Composite, similar to Dai et al. (2016). We standardize each of the three measures, $R \& D$, Patents, and Product Similarity, to have 
zero mean and unit variance, and then sum these standardized values to obtain Composite. ${ }^{10}$

\subsection{Insider Trading Variables}

We measure the intensity or amount of insider purchases, Purchases, as the total number of shares purchased by insiders during the year, scaled by the total number of shares outstanding at the beginning of the year. This measure is similar to those employed by prior research (Beneish and Vargus 2002; Piotroski and Roulstone 2005; Jagolinzer et al. 2011). Since Purchases is the ratio of the shares traded by insiders to the total number of shares outstanding, the range of the variable is a small positive interval around zero. Therefore, to preserve significant digits of the coefficient estimates on the independent variables, we multiply Purchases by 1,000.

We use three measures of trading profits estimated over the 360 calendar days subsequent to the purchase date. First, following recent literature on insider trading (Jagolinzer et al. 2011; Gao et al. 2014; Dai et al. 2015, 2016), we use daily alpha, Alpha, the intercept from the Carhart (1997) four-factor model. Second, similar to Ravina and Sapienza (2010) and Dai et al. (2016), we use buy-and-hold abnormal stock returns, BHAR, estimated using Carhart's (1997) four-factor model. The third measure is buy-and-hold raw stock returns, BHRaw. We measure insider trading profits over a twelve-month horizon which is a reasonable period because Section 16(b) of the Securities and Exchange Act of 1934 requires insiders to disgorge "short-swing profits" made within 180 days. $^{11}$

\subsection{Summary Statistics}

Descriptive statistics and correlation coefficients are provided in Panels A and B of Table 2. Insider purchases are relatively rare and occur in fewer than $25 \%$ of firm-year observations. All

\footnotetext{
${ }^{10}$ Including Tech Similarity (Tech Similarity and Competition Words) results in a sample size reduction of 55\% (65\%). Our results and inferences remain qualitatively similar with these augmented composite measures.

${ }^{11}$ Results are qualitatively similar when we estimate trading profits using a six-month period.
} 
proprietary cost measures, except Tech Similarity, exhibit substantial variation with high standard deviations. By construction, $R \& D$, Patents, and Product Similarity are each highly positively correlated with Composite (Pearson correlation coefficients range between 0.429 and 0.699). Tech Similarity and Competition Words are also positively correlated with Composite (0.504 and 0.190, respectively). The correlations between the individual measures are more varied with the Pearson correlations ranging from $0.431(R \& D$ and Tech Similarity) to -0.167 (Product Similarity and Competition Words). Hence, they capture different dimensions of proprietary costs and, as such, allow the composite measure to capture proprietary costs for a wide variety of firms.

\section{Analyses and Results}

In this section, we present our empirical analyses and results of the associations between proprietary costs and insider purchases, profitability, and the potential mechanisms through which proprietary costs are associated with insider purchases.

\subsection{Proprietary Costs and Insider Purchases}

To analyze the association between proprietary costs and insiders' purchase decisions, we estimate the following tobit regression model for firm $i$ in year $t$ :

$$
\begin{aligned}
\text { Purchases }_{i, t}=\alpha & +\beta_{1} \text { Prop Cost }_{i, t-1}+\beta_{2} \text { Size }_{i, t-1}+\beta_{3} \text { BM }_{i, t-1}+\beta_{4} \text { BHRaw }_{i, t-1}+\beta_{5} \text { Coverage }_{i, t-1} \\
& +\beta_{6} \text { InstOwn }_{i, t-1}+\beta_{7} \text { Turnover }_{i, t-1}+\beta_{8} \text { Litigation }_{i, t-1}+\beta_{9} \text { Volatility }_{i, t-1} \\
& +\sum \gamma_{j} \text { Industry }_{j}+\sum \delta_{t} \text { Year }_{t}+\varepsilon_{i, t}
\end{aligned}
$$

where the dependent variable, Purchases, is the total number of shares purchased by insiders during the year, scaled by the total number of shares outstanding at the beginning of the year, multiplied by 1,000. The main variable of interest, Prop Cost, is measured using one of the five individual proprietary cost measures and the composite measure, Composite, as defined in Section 3.2. We employ a tobit model because for the majority of the sample, the value Purchases equals 
zero, which corresponds to the corner solution (type I) tobit model (Wooldridge 2010). ${ }^{12}$

We include as control variables several firm characteristics that have been documented in prior research to affect insider trading decisions (Aboody and Lev 2000; Frankel and Li 2004; Gao et al. 2014; Huddart et al. 2007; Ke et al. 2003; Lakonishok and Lee 2001; Piotroski and Roulstone 2005; Ravina and Sapienza 2010). Specifically, we include firm size, Size; book-to-market ratio, $B M$; raw stock returns over the prior year, BHRaw; analyst coverage, Coverage; institutional ownership, InstOwn; share turnover, Turnover; and stock return volatility, Volatility. Prior research shows insider trading is associated with litigation risk (Billings and Cedergren 2015; Cheng and Lo 2006). As we discuss in Appendix B, we do not expect litigation risk to influence insider purchase decisions as litigation risk mainly arises from insider sales. Nevertheless, we include the ex-ante litigation risk measure of Kim and Skinner (2012), Litigation. Finally, we include industry and year fixed effects to control for systematic variation in insider trading both across industries and over time. Standard errors are clustered by firm and year (Petersen 2009). All variable definitions for this and subsequent tests are provided in Appendix A.

Table 3 presents the results from estimating Equation (1). Column (1) reports the results using Composite as the measure of proprietary costs. Columns (2) to (6) report the results using each of the five individual measures of proprietary costs. In Column (1), the Prop Cost coefficient is negative and significant $(t$-statistic $=-3.52)$, as expected. The negative sign is consistent with insiders reducing their insider purchase activities in high proprietary cost firms. In economic terms, a one standard deviation increase in proprietary costs is associated with a 0.289 share decrease in

\footnotetext{
$1273.99 \%$ of observations have values of Purchases equal to zero when Composite is used to measure proprietary costs. The tobit model relies on stricter assumptions about the functional form of the error term, and is less flexible to include fixed effects. In sensitivity tests, we estimate Equation (1) using OLS and logistic regression models (using the likelihood of an insider purchase as the measure of insider purchase activity in the logistic regression). Results are qualitatively similar across these alternative specifications.
} 
the predicted value of Purchases, which is a $46.62 \%$ decrease relative to the sample mean purchases. ${ }^{13}$ This form of marginal effects describes how the unobserved latent trading incentives change with respect to changes in proprietary costs. An alternative type of marginal effect is with respect to the observed trading activities, namely how the expected value of the observed Purchases changes as proprietary costs change. This estimated marginal effect is -0.035 , which represents a $10.39 \%$ decrease relative to the mean shares purchased by insiders.

Similar to the results in Column (1), the results in Columns (2) to (6) show each of the Prop Cost coefficients are negative and significant ( $t$-statistics range from -2.02 to -3.21 ). Thus, even though each individual measure captures different aspects of proprietary costs, each is negatively associated with insider purchase activity. This similarity lends confidence that our results are being driven by insiders' considerations of the competitive costs associated with their trading behavior. Collectively, the results in Table 3 support Hypothesis 1.

The coefficients on control variables are generally consistent with prior literature. Focusing on the results in Column (1), insider purchases are negatively associated with firm size, institutional ownership, and lagged stock returns, and positively associated with book-to-market ratio (i.e., value firms). Insider purchases are not significantly associated with analyst coverage, stock turnover, and volatility. ${ }^{14}$ In addition, the Litigation coefficient is positively associated with insider purchases. ${ }^{15}$

In order to assess the robustness of the results, we re-estimate Equation (1) using three

\footnotetext{
13 The standard deviation of Composite is 1.84 and the mean of Purchases is 0.62 for the sample used in Column (1). ${ }^{14}$ A potential alternative explanation is that firms' profits are more uncertain in highly competitive product markets, and hence, insiders reduce their purchases due to higher uncertainty in realizing their trading profits and not due to proprietary costs (Peress 2010). The fact that volatility is insignificant in five of the six specifications (and weakly positively significant in the sixth specification) limits the plausibility of this alternative explanation.

15 The Litigation coefficient is also significantly positive in Columns (4) and (6) and insignificant in Columns (2), (3), and (5). The positive coefficients are inconsistent with litigation risk deterring insider purchases (see Appendix B).
} 
alternative measures of insider purchases: i) the dollar value of purchases scaled by the firm's beginning-of-year market capitalization, ii) the number of purchase transactions scaled by the number of active insiders, where active insiders are defined as insiders who have at least one insider stock transaction during our sample period (Ke et al. 2003; Peress 2010), and iii) the likelihood of at least one insider purchase occurring (Massa et al. 2015). The untabulated results are qualitatively similar to those in Table 3 and our inferences remain unchanged.

\section{Opportunistic versus Routine Trading}

Cohen et al. (2012) classify insider trading as "routine" (and hence, less likely to be based on private information) or "opportunistic" (and hence, more likely to be based on private information). Consistent with their classification, they find opportunistic insider trading has higher informational value in terms of predicting future firm stock returns, news, and events, compared to routine insider trading. If concerns about proprietary costs influence insiders' trading decisions, then we expect these concerns will affect opportunistic trades more than routine trades, as they are likely to attract greater attention from outside observers, including rivals.

To test this prediction, we follow Cohen et al. (2012) and classify insider purchases as opportunistic or routine. If an insider trades in the same month for three consecutive years, then all subsequent trades by this insider are classified as routine trades. If an insider trades in three consecutive years but no trades are made in the same month, then all subsequent trades are classified as opportunistic. ${ }^{16}$ Given insiders' highly undiversified portfolios, insider purchases are often thought to be primarily motivated by private information; in other words, routine purchases are uncommon. However, as discussed in Cohen et al. (2012), routine purchases often occur after

\footnotetext{
${ }^{16}$ Cohen et al. (2012) discuss an alternative classification scheme based on trade-level patterns. Untabulated results are qualitatively similar and our inferences remain unchanged when we use this alternative classification scheme.
} 
an insider receives a bonus and bonuses are generally paid out in the same month each year.

Based on this classification scheme, 24,358 purchase transactions (22\%) are classified as routine, 15,713 (15\%) as opportunistic, and 68,719 (63\%) are unclassified. Clearly, this scheme produces classification errors by misclassifying trades based on private information as routine and vice-versa. These errors will decrease our ability to reject the null hypothesis of no differences in the associations between proprietary costs and trading for routine and opportunistic purchases.

Panel B presents the results from estimating Equation (1) separately for opportunistic and routine purchases, where unclassified purchases are excluded. The results indicate that proprietary costs have a significantly negative association with opportunistic purchases, but not with routine purchases. Except when Competition Words is used to proxy for proprietary costs, all of the Prop Cost coefficients are negative and significant ( $t$-statistics range from -2.08 to -3.55 ) when opportunistic purchases is the dependent variable. In contrast, there is little evidence that proprietary costs are significantly associated with routine purchases, as all but one of the Prop Cost coefficients are statistically insignificant. Moreover, Wald chi-square tests indicate that for five of the six proprietary cost measures (not $R \& D$ ), the Prop Cost coefficients are significantly different between the opportunistic and routine regressions ( $p$-values range from $<0.01$ to 0.06 ).

Overall, the results in Table 3 suggest that insiders reduce their insider purchase activities when proprietary costs are high. Furthermore, the reductions are concentrated among trades that are most likely to be based on private information, and hence, where proprietary costs will be larger. In contrast, insiders at higher proprietary cost firms do not appear to reduce purchases that have little to no informational value. Together, these results provide further support for Hypothesis 1 and are consistent with insiders limiting their insider trading to avoid the risk of revealing proprietary information, which would negatively affect their competitive position. 


\subsection{Proprietary Costs and Insider Trading Profits}

In this section, we examine whether insiders' abnormal trading profits are higher when proprietary costs are higher. We estimate the following OLS regression at the insider-purchase date level for insider $k$ in firm $i$ on day $d$ and year $t$ :

$$
\begin{aligned}
\text { Profit }_{k, i, d, t}=\alpha & +\beta_{1} \text { Composite }_{i, t-1}+\beta_{2} \text { Size }_{i, t-1}+\beta_{3} \text { BM }_{i, t-1}+\beta_{4} \text { PreRet }_{i,[-380 ;-20]} \\
& +\beta_{5} \text { Coverage }_{i, t-1}+\beta_{6} \text { InstOwn }_{i, t-1}+\beta_{7} \text { Turnover }_{i,[-380 ;-20]} \\
& +\beta_{8} \text { Volatility }_{i,[-380 ;-20]}+\beta_{9} \text { TradeSize }_{k, i, d, t}+\sum \gamma_{j} \text { Industry }_{j}+\sum \delta_{t} \text { Year }_{t}+\varepsilon_{k, i, d, t}
\end{aligned}
$$

where the dependent variable is insider trading profits, Profit, measured alternatively using daily alpha (Alpha), buy-and-hold abnormal stock returns (BHAR), and buy-and-hold raw stock returns (BHRaw) over the 360 calendar days subsequent to the transaction dates.

Following Brochet (2010), Ravina and Sapienza (2010), and Gao et al. (2014), we include firm- and transaction-level control variables. Firm-level controls are firm size (Size), book-tomarket ratio $(B M)$, analyst following (Coverage), and institutional ownership (InstOwn). Transaction level controls include momentum $\left(\right.$ BHRaw $\left._{[-380,-20]}\right)$, share turnover $\left(\right.$ Turnover $\left._{[-380,-20]}\right)$, stock return volatility (Volatility $[-380,-20]$ ), and trade size (TradeSize). We include industry and year fixed effects and cluster standard errors by firm and year.

Panel A of Table 4 reports the results from estimating Equation (2). ${ }^{17}$ The results indicate insiders of firms with higher proprietary costs earn significantly higher profits from their purchase transactions ( $t$-statistics range from 2.86 to 3.27 ). The economic magnitudes are significant as well. When daily alpha is used to measure profitability, a one standard deviation increase in proprietary costs is associated with an increase of daily abnormal stock returns of 1.455 basis points, which corresponds to a $3.67 \%$ increase in annual returns. The marginal effects are stronger when the other two profitability measures are used: insiders earn $5.33 \%(5.01 \%)$ higher abnormal returns

\footnotetext{
${ }^{17}$ For parsimony, we only tabulate results using Composite in this and subsequent tables.
} 
(raw returns) annually. ${ }^{18}$ Overall, these findings suggest that when insiders purchase shares when proprietary costs are higher, their trades are more likely to be based on (more valuable) private information. As such, these findings provide empirical support for Hypothesis 2 and suggest proprietary costs increase the "hurdle rate" insiders use to evaluate purchase opportunities.

Cohen et al. (2012) suggest the profitability of insider trades is derived mainly from opportunistic trading. Accordingly, we estimate Equation (2) separately for opportunistic trades and routine trades. The results are presented in Panel B. The results for all three profitability measures show the Composite coefficients are positive and significant ( $t$-statistics range from 2.22 to 2.37) for opportunistic purchases. In addition, the magnitudes of the Composite coefficients are about twice as large as their full sample counterparts in Panel A. In contrast, only one (two) of the Composite coefficients are significantly positive at the $1 \%(10 \%)$ level for routine purchases. Furthermore, Wald chi-square tests reject the null hypothesis that the association between insider purchase profitability and proprietary costs is equal for opportunistic and routine purchases (all $p$ values $<0.01)$. Thus, the results indicate that opportunistic insiders at firms with higher proprietary costs make relatively higher profits from their purchases when they trade despite high proprietary costs. These results provide further support for Hypothesis 2.

\subsection{Event-Driven Changes in Proprietary Costs}

The evidence above is consistent with proprietary costs reducing insider purchases. However, it is possible our proprietary cost measures are correlated with other unobservable and time-varying firm characteristics that also drive insider purchase decisions. To help alleviate this concern, we examine two distinct events for which proprietary information risk is expected to be heightened. These analyses enable us to exploit event-driven variation in proprietary costs.

\footnotetext{
${ }^{18}$ In untabulated analyses, we obtain quantitatively similar results using a 180-calendar-day holding period.
} 


\subsubsection{Insider Purchases before Product Launches}

We examine how insider purchases are related to new product announcements. We expect proprietary information risk is especially high prior to the launch of new products because insider purchases may reveal the progress and the likely success of product development efforts to rival firms. Consistent with this concern, insider trading policies state that insiders are not allowed to trade based on "material" information, and frequently specify that data or information regarding products under development are deemed material. Moreover, firms often employ event-specific blackout periods such as periods prior to the announcements of new product development, clinical trials or mergers and acquisitions, in addition to quarterly blackout periods prior to earnings announcements (Bettis et al. 2000). Therefore, we expect insiders are more likely to refrain from trading during product development periods, when proprietary costs are especially high.

We gather product related announcements for the period from 2002 to 2017 from S\&P Capital IQ. This database starts in 2002 and includes mostly unscheduled corporate information events from newswires and newspapers, including Reuters, Dow Jones, Comtex, Regulatory News Service, Bloomberg Business News, CNN, and CBS. To ensure the product announcements are related to new products, we restrict the press releases to include either "introduce" and "new" or "launch" and "new" in the headlines. To account for the possibility of a selection bias due to Capital IQ's coverage decisions, we restrict the sample to firms with at least one product announcement during the sample period. We exclude firm-year observations that cannot be uniquely classified as either a product development period (hereafter "proprietary period") or a non-product development period (hereafter "non-proprietary period"). This procedure results in 1,512 new product announcements in 1,202 firm-years. 
To test whether insiders reduce purchase activities during proprietary periods, we estimate the following tobit regression model for firm $i$ in year $t$ :

$$
\begin{aligned}
\text { Purchases }_{i, t}=\alpha & +\beta_{1} \text { Prop Period }_{i, t}+\beta_{2} \text { Size }_{i, t-1}+\beta_{3} \text { BM }_{i, t-1}+\beta_{4} \text { BHRaw }_{i, t-1}+\beta_{5} \text { Coverage }_{i, t-1} \\
& +\beta_{6} \text { InstOwn }_{i, t-1}+\beta_{7} \text { Turnover }_{i, t-1}+\beta_{8} \text { Litigation }_{i, t-1}+\beta_{9} \text { Volatility }_{i, t-1} \\
& +\sum \gamma_{j} \text { Industry }_{j}+\sum \delta_{t} \text { Year }_{t}+\varepsilon_{i, t}
\end{aligned}
$$

where the main variable of interest is Prop Period, which is an indicator variable equal to one if the firm-year is in a proprietary period, and zero otherwise. Proprietary periods are identified using two alternative approaches: i) year $t$ is a proprietary period for firm $i$ if the firm has at least one product announcement in years $t+1$ or $t+2$ but no announcement in year $t$, and ii) year $t$ is a proprietary period for firm $i$ if the firm has at least one product announcement in year $t+1$ but no announcement in year $t$. We cluster standard errors by firm and year.

Table 5 Columns (1) and (2) present the results from estimating Equation (3) with proprietary periods identified using approach i) and ii), respectively, as detailed above. The coefficients on Prop Period are negative and significant $(t$-statistics $=-4.40$ and -2.59 , respectively). The magnitudes of the Prop Period coefficients indicate insiders purchase $10.37 \%$ and $6.06 \%$ fewer shares during proprietary period than during non-proprietary periods, respectively. This result is consistent with insiders significantly reducing purchases prior to new product announcements to minimize the risk of information leakage.

As an alternative estimation procedure, we divide the sample based on whether the observations are during a proprietary period or a non-proprietary period. We estimate Equation (1) separately on each sub-sample. Doing so allows us to distinguish the effects of proprietary costs during periods when insiders are expected to be more or less cognizant of potential information leakage. The results in Columns (3) and (4) show that during high proprietary cost periods, the Composite coefficients are negative and significant $(t$-statistics $=-10.35$ and -4.05 , respectively). 
In contrast, the Composite coefficient in Column (5) is insignificant ( $t$-statistic $=-0.72)$ during non-proprietary periods when potential information leakage concerns are expected to be lower.

Overall, the results in Table 5 are consistent with insiders taking into account potential proprietary costs during periods before product launch announcements when making their purchase decisions. These findings provide additional evidence supporting Hypothesis 1.

\subsubsection{Insider Purchases following Tariff Reductions}

We use large reductions in U.S. import tariff rates as an exogenous increase in proprietary costs. Tariff rate reductions significantly increase competition, and hence, increase proprietary costs for U.S. domestic firms (Fresard 2010; Valta 2012; Xu 2012; Fresard and Valta 2016; Huang et al. 2017). For instance, Valta (2012) documents that over his sample period, the average tariff rates dropped by 1.5 percentage points and import penetration substantially rose from $19.5 \%$ to 24.1\%. Similarly, Xu (2012) reports a significant decrease of profit margins for U.S. domestic firms following large tariff rate reductions, which indicates they intensify competition.

Theoretical models of voluntary disclosure suggest that the effect of competition on disclosure depends on whether the competitive threat comes from existing rivals or potential entrants. Theories of competition among existing rivals focus on the proprietary costs associated with disclosure, and generally conclude that competition discourages disclosure because it undermines the disclosing firm's competitive position (Verrecchia 1983, 1990). In contrast, entry game models generally suggest potential competition encourages firms to disclose bad news to

deter entry (Darrough and Stoughton 1990; Wagenhofer 1990). Huang et al. (2017) argue tariff rate reductions mainly increase competition from existing foreign rivals rather than from potential 
foreign entrants who decide to enter the market following the tariff reductions. ${ }^{19}$ Thus, the increase in competition following tariff reductions comes from existing rivals. Consequently, we expect insiders' purchase decisions are more sensitive to proprietary costs following tariff reductions.

We collect U.S. import data for the period from 1989 to 2017 and compute the tariff rate for each industry-year at the three-digit SIC level. Tariff rates are calculated as the duties collected at U.S. Customs divided by the Free-On-Board custom value of imports. Following prior literature (Fresard 2010; Valta 2012; Xu 2012; Fresard and Valta 2016; Huang et al. 2017), we focus on large reductions in import tariff rates..$^{20}$ In line with prior work (Fresard 2010; Valta 2012; Fresard and Valta 2016; Huang et al. 2017), industry-years are classified as having a large reduction if the reduction is larger than three times the median reduction in the industry over the sample period. This procedure results in 71 industries with a large tariff reduction from 1990 to 2017.

To investigate the effect of large reductions in import tariff rates on insider purchases, we follow prior literature and estimate the following regression model for firm $i$ in year $t$ :

$$
\begin{aligned}
\text { Purchases }_{i, t}=\alpha & +\beta_{1} \text { Post Reduction }_{i, t}+\beta_{2} \text { Size }_{i, t-1}+\beta_{3} \text { BM }_{i, t-1}+\beta_{4} \text { BHRaw }_{i, t-1} \\
& +\beta_{5} \text { Coverage }_{i, t-1}+\beta_{6} \text { InstOwn }_{i, t-1}+\beta_{7} \text { Turnover }_{i, t-1}+\beta_{8} \text { Litigation }_{i, t-1} \\
& +\beta_{9} \text { Volatility }_{i, t-1}+\sum \gamma_{j} \text { Industry }_{j}+\sum \delta_{t} \text { Year }_{t}+\varepsilon_{i, t}
\end{aligned}
$$

where the main variable of interest is Post Reduction, an indicator variable equal to one if firm $i$ 's industry experiences a significant tariff reduction by year $t-1$ that is larger than three times the median tariff rate reduction in that industry over the sample period, and zero otherwise. The Post Reduction coefficient captures the change in insider purchases in tariff cut industries relative to

\footnotetext{
${ }^{19}$ Supporting this argument, Huang et al. (2017) find that while imports increase by $36 \%$ in the tariff reduction years (suggesting an immediate response by existing foreign rivals), they only increase from $3 \%$ to $8 \%$ in the subsequent two years (potentially related to new foreign rivals).

${ }^{20}$ To ensure that these reductions reflect non-transitory changes in the competitive landscape, we exclude reductions that have equivalently large increases in tariff rates the following year.
} 
the concurrent change in insider purchases in non-tariff cut industries. We cluster standard errors by industry and year as the tariff reductions occur at the industry level (Petersen 2009).

Table 6 Column (1) presents the results from estimating Equation (4) using all available observations. The coefficient on Post Reduction is negative and significant $(t$-statistic $=-2.42)$. This result indicates that relative to control firms, firms in industries that experience a large tariff reduction have a significant reduction in insider purchases. In economic terms, insiders in these firms reduce purchases by $14.66 \%$ after a large tariff reduction relative to control firms. This finding is consistent with insiders reducing purchases due to heightened concerns about proprietary information risk following tariff reductions.

In several respects, tariff reductions provide a good setting for examining the link between proprietary costs and insider trading. First, tariff reductions satisfy the relevance condition. As discussed above, tariff rate reductions have been shown to significantly increase competition, and hence, increase proprietary costs faced by domestic firms. Second, as discussed in related work, tariff rate reductions satisfy the exclusion condition because they are exogenous to insider trading decisions. ${ }^{21}$ However, the exclusion restriction will not hold if tariff reductions affect the firm in ways that directly influence insider purchase decisions beyond any effect attributable to changes in proprietary costs. For example, if tariff reductions reduce future firm profits, insiders may purchase fewer shares for reasons that are unrelated to the increase in proprietary costs. Thus, an alternative explanation for the results presented in Column (1) is that insiders reduce their purchases because the tariff reductions reduce their firms' prospects.

In order to provide evidence on this alternative explanation, we examine whether the results

\footnotetext{
${ }^{21}$ Another advantage of this setting is that a given firm will be both a treatment and a control firm at different points in time due to the staggered introduction of tariff reductions. This aspect reduces concerns about systematic differences between treatment and control firms, and alleviates concerns the results are confounded by other concurrent events.
} 
in Column (1) hold for firms with relatively high and low cash holdings. Prior studies document that high cash reserves provide firms with a competitive advantage compared to their competitors (Fresard 2010; Fresard and Valta 2016). As a result, when faced with high levels of competition (including increases in competition due to tariff reductions), firms with high cash holdings experience improvements in product market share, firm value, and operating performance (Fresard 2010; Fresard and Valta 2016). Accordingly, we classify affected firm-year observations into high and low cash holdings where high (low) cash holdings firms are firms above (below) the median industry cash holdings in the year prior to the tariff reduction. We estimate Equation (4) separately for high and low cash holdings firms. The results are reported in Columns (2) and (3) and show both Post Reduction coefficients are significantly negative $(t$-statistics $=-1.82$ and -1.82 , respectively). Additionally, the magnitudes of the Post Reduction coefficients for the high and low cash holdings firms $(-0.424$ and -0.367 , respectively) are not significantly different ( $p$-value $=$ 0.78). Thus, these results are not consistent with this alternative explanation.

Overall, the results in Table 6 support the deterrence effect of proprietary costs on insider purchases. Specifically, the evidence suggests firms in industries that experience a large tariff reduction have a significant reduction in insider purchases. Furthermore, this reduction does not appear to be driven by concerns over deteriorating future performance, but rather concerns over proprietary information risk. These findings provide additional evidence supporting Hypothesis 1.

\subsection{Proprietary Costs and Insider Purchases by Informativeness of Insider Trading}

An implication of Hypothesis 1 is that the negative association between proprietary costs and insider purchases will be more pronounced when insider trades are more likely to be informative to rivals. We use three proxies for the amount of private information that can be inferred from insider trades (top executives versus non-top executives, high-complexity versus 
low-complexity firms, and small versus large firms). For each proxy, we divide the sample into two sub-samples based on the private information proxy. We then separately estimate Equation (1) for each sub-sample. The results are presented in Table 7.

Top executives are the most likely to possess proprietary information (Peress 2010; Cheng et al. 2016), and hence competitors would consider insider trading by top executives more informative. Accordingly, we examine whether the association between proprietary costs and insider purchases is stronger for top executives compared to non-top executives and directors. We classify each insider purchase as completed by a top five insider (CEO, CFO, COO, President, and Chairman of Board) or a non-top five insider (other officers and directors). ${ }^{22}$ The results are reported in Columns (1) and (2). As expected, the Composite coefficient is negative and significant for top five insider purchases $(t$-statistic $=-3.52)$, but is insignificant for non-top five purchases $(t$ statistic $=1.07)$. Furthermore, the magnitudes of the coefficients $(-0.157$ and 0.044 , respectively $)$ are significantly different $(p$-value $<0.01)$. Thus, the evidence is consistent with top-level insiders being more sensitive to potential proprietary costs and reducing their purchases accordingly.

We expect a firm's complexity to be associated with the amount of private information that can be conveyed by insiders' purchase decisions. Frankel et al. (2006) find analyst reports are less informative for firms with multiple segments because of high information processing costs. Similarly, we expect the difficulty for rivals to interpret and draw specific implications about the firm's prospects and its products from insider purchases is increasing with firm complexity. Thus, the ability of rivals to act on insider trading signals (and hence, impose proprietary costs on the insiders' firms) is decreasing with complexity. In which case, we expect the negative association between proprietary costs and insider purchases is stronger for low-complexity firms.

\footnotetext{
${ }^{22}$ Thus, for this test (and this test only), we include non-top five insider purchase transactions.
} 
We classify firm-year observations into low and high complexity sub-samples, where the low (high) complexity sub-sample consists of firms with single (multiple) business or geographic segments for the year. The results are reported in Columns (3) and (4). They show both of the Composite coefficients are significantly negative, although only marginally so for the highcomplexity sub-sample ( $t$-statistics $=-3.39$ and -1.93 , respectively). Furthermore, the magnitudes of the coefficients $(-0.307$ and -0.089 , respectively) are significantly different ( $p$-value $<0.01)$. Thus, the evidence suggests that insiders at less complex firms are relatively more sensitive to potential proprietary costs.

Similar to complexity, we expect the ability for rivals to interpret and act on insider trading signals is decreasing with firm size. In addition to small firms being less likely to be complex, small firms may face higher proprietary information risk as they are likely more vulnerable to potential actions by rivals (Bernard 2016). Hence, we expect the negative association between proprietary costs and insider purchases is relatively stronger for small firms. To test this prediction, we classify firm-year observations into small and large sub-samples, where small (large) firms are firms below (above) the median industry market value of equity at the beginning of the year. The results, presented in Columns (5) and (6), are consistent with our prediction. Both of the Composite coefficients are significantly negative ( $t$-statistics $=-3.14$ and -2.56 , respectively). Furthermore, the magnitudes of the coefficients $(-0.231$ and -0.075 , respectively) are significantly different $(p$ value $<0.01)$. Thus, the evidence indicates insiders at smaller firms are relatively more sensitive to proprietary costs.

Finally, we investigate whether the negative association between proprietary costs and insider purchases is more pronounced for firms with higher media coverage. Dai et al. (2015) show the media plays an important role in disseminating insider trading information. Hence, firms facing 
high proprietary costs of disclosure are likely to reduce their purchase activity more when media coverage on insider trading is higher. Thus, we expect the negative association between proprietary costs and insider purchases will be increasing with media coverage. To test this prediction, we classify firm-year observations into high and low media coverage sub-samples, where high (low) media coverage firms are firms above (below) the median industry news coverage on insider trading in the same size decile in the prior year. The results, presented in Columns (7) and (8), are consistent with our prediction. Both of the Composite coefficients are significantly negative ( $t$ statistics $=-3.34$ and -2.02 , respectively). Furthermore, the magnitudes of the coefficients $(-0.179$ and -0.081 , respectively) are significantly different $(p$-value $=0.08)$. Thus, the evidence is consistent with insiders at firms with high media coverage are relatively more sensitive to potential proprietary costs.

To summarize, the four sets of results presented in Table 7 indicate the negative association between proprietary costs and insider purchases is more pronounced for top-level insiders, insiders at less complex firms, at smaller firms, and at firms with high media coverage. Overall, these findings are consistent with proprietary costs reducing insiders' purchase activity to a greater extent when insider purchases are more likely to be informative to rivals or disseminated more widely. Collectively, these results provide additional support for Hypothesis 1.

\subsection{Why Do Insiders Reduce Trades in the Presence of Proprietary Costs?}

The evidence discussed above strongly supports Hypotheses 1 and 2, and collectively indicates that insiders' purchase decisions are associated with their firms' proprietary costs. A remaining question is: what is the mechanism or channel which causes insiders to internalize proprietary costs that are borne by shareholders into their private trading decisions? In this section, 
we explore two potential mechanisms through which proprietary costs are associated with reduced insider trading activities.

\subsubsection{Proprietary Costs and Insider Trading Restrictions}

When firms face high proprietary costs, one way they can directly limit the information flow from insider trading is by either imposing new policies restricting insider trading or more strictly enforcing existing policies. Insider trading policies typically specify "safe" trading windows during which insiders can trade and "blackout" periods during which trading is prohibited (Bettis et al. 2000; Roulstone 2003; Jagolinzer et al. 2011). The most commonly-used safe (blackout) periods are just subsequent (prior) to quarterly earnings announcements. ${ }^{23}$

To examine whether firms with higher proprietary costs are more likely to impose insider trading restrictions, we estimate the following regression model for firm $i$ in year $t$ :

$$
\begin{aligned}
\text { Safe }_{\text {Trades }}^{i, t}=\alpha & +\beta_{1} \text { Composite }_{i, t-1}+\beta_{2} \text { Size }_{i, t-1}+\beta_{3} \text { BM }_{i, t-1}+\beta_{4} \text { BHRaw }_{i, t-1} \\
& +\beta_{5} \text { Coverage }_{i, t-1}+\beta_{6} \text { InstOwn }_{i, t-1}+\beta_{7} \text { Turnover }_{i, t-1}+\beta_{8} \text { Litigation }_{i, t-1} \\
& +\beta_{9} \text { Volatility }_{i, t-1}+\sum \gamma_{j} \text { Industry }_{j}+\sum \delta_{t} \text { Year }_{t}+\varepsilon_{i, t}
\end{aligned}
$$

where the dependent variable, Safe Trades, is the percentage of safes trades using three-year rolling windows, where a safe trade is an insider trade made within one month following a quarterly earnings announcement. We cluster standard errors by firm and year.

As an alternative specification, we estimate a logistic regression and substitute Safe Trades with Insider Trading Restriction, which is an indicator variable equal to one if the firm imposes insider trading restrictions, and zero otherwise. We follow Roulstone (2003) and infer the presence of an enforced insider trading policy in year $t$ if the percentage of safe trades is greater than or

\footnotetext{
${ }^{23}$ Even though blackout periods are the most common way firms restrict insider trading, they also employ other types of restrictions. For instance, Jagolinzer et al. (2011) document 80\% of their 260 sample firms with insider trading policies require insider trades to be pre-approved by the general counsels. Hence, we expect our identification of insider trading window restrictions also proxies for more restrictive insider trading policies, such as those requiring general counsel approval.
} 
equal to $75 \%$ based on a three-year rolling window beginning in year $t$. The $75 \%$ cutoff is based on the survey findings in Bettis et al. (2000), who show that insiders are three times more likely to trade in allowed trading periods than during blackout periods, and Jagolinzer et al. (2011), who find $24 \%$ of insider trades occur during blackout periods. ${ }^{24}$ The OLS and logistic results are presented in Panel A of Table 8, Columns (1) and (2), respectively. In both columns, the Composite coefficient is positive and significant ( $t$-statistics $=2.18$ and 2.33 , respectively). These results indicate that when proprietary costs are higher, firms are significantly more likely to impose insider trading restrictions. As such, the evidence in Panel A supports Hypothesis 3A.

\subsubsection{Executives' Incentive Alignment}

Another mechanism which may cause insiders to internalize the proprietary costs of their trades is the degree of incentive alignment between insiders and shareholders. When insiders' wealth is more closely linked to their firm's performance, insiders internalize more of the potential erosion of the firm's competitive advantage caused by their insider trading. Thus, when incentives are more closely aligned, insiders are more likely to "voluntarily" reduce their trading activities even in the absence of explicit insider trading policies. Accordingly, Hypothesis 3B predicts the negative association between insider purchases and proprietary costs is stronger when insiders have greater ownership. To examine this prediction, we classify firm-year observations into high and low ownership sub-samples, where high (low) ownership firms are firms above (below) the median industry-year share ownership held by top-level executives. We estimate Equation (1) for each sub-sample separately.

\footnotetext{
${ }^{24}$ Using data on actual insider trading restrictions, Jagolinzer et al. (2011) find this method produces reasonably accurate classifications $(81.13 \%$ (90.02\%) correct classification of trades occurring inside (outside) the restriction window). However, they no longer find significant results when using inferred windows. They conclude researchers "should exercise caution when interpreting null results based on inferred windows." As discussed below, we find significant results for our restriction tests, and hence, their caution is not applicable in our case.
} 
The results are presented in Panel B of Table 8. For both sub-samples, the Composite coefficient is negative and significant ( $t$-statistics $=-3.22$ and -2.81 , respectively). Furthermore, the magnitudes of the coefficients (-0.235 vs. -0.105 , respectively) are significantly different $(p$ value $=0.03$ ). Thus, the evidence suggests insiders with relatively high ownership stakes being more sensitive to potential proprietary costs and incorporating these costs into their trading decisions. As such, these results support Hypothesis 3B.

In summary, the results in Table 8 suggest that when proprietary costs of insider trading are high, firms are more likely to impose insider trading restrictions. In addition, insiders selfdiscipline their trading behavior when their incentives are more highly aligned with shareholders. Thus, these findings provide evidence of potential and non-exclusive mechanisms through which proprietary costs are associated with reduced insider trading activities.

\section{Conclusion}

Prior literature has extensively investigated the potential determinants and consequences of insider trading, with an emphasis on its capital market implications. In additional, voluntary disclosure studies have long examined the capital market benefits and competitive costs of disclosure. In this paper, we argue insider trading can reveal proprietary information to rivals and analyze whether insiders' trading decisions reflect these proprietary costs. We focus on insider purchases because they are more likely based on private information compared to insider sales and are unlikely to entail litigation and regulatory costs. We expect insiders at high proprietary cost firms have incentives to avoid revealing proprietary information through their trading activities, and thus, we hypothesize that proprietary costs are negatively associated with insider purchases.

Using a variety of proxies for proprietary costs, we find a negative association between proprietary costs and insiders purchases. We also find that when insiders trade despite higher 
proprietary costs, they earn significantly higher abnormal profits. The results of several crosssectional analyses show the negative association between proprietary costs and insider purchases is stronger when the purchases are more likely to be informative or useful to rivals. These results are consistent with our main tests and further support the idea that insiders take proprietary costs into consideration when making their trading decisions.

In addition, we examine two event-driven settings to identify changes in proprietary costs. First, we examine insider purchases prior to new product launches, when we expect proprietary information risk is particularly high. We find insiders significantly reduce their purchases during this period. Second, we examine purchase behavior following large reductions in U.S. import tariff rates, which introduce an exogenous increase in proprietary costs. The results show insiders significantly reduce their purchases when their industries experience large tariff reductions relative to insiders in unaffected industries. Finally, we investigate two mechanisms by which insiders incorporate proprietary costs that are borne by shareholders. First, we show firms with higher proprietary costs are more likely to impose new insider trading restrictions or more strictly enforce existing policies. Second, we find insiders' trading activities are more sensitive to proprietary costs when their wealth is more closely linked to that of shareholders.

Overall, the evidence in this study suggests product market considerations are an important, but previously undocumented, factor associated with insider trading decisions and profitability. These findings are likely to be of interest to regulators and corporate boards in setting insider trading policies, and help investors make investment decisions using insider trading signals. 


\section{References}

Aboody, David, and Baruch Lev. 2000. "Information Asymmetry, R\&D, and Insider Gains." The Journal of Finance 55(6): 2747-66.

Aghion, Philippe, Nick Bloom, Richard Blundell, Rachel Griffith, Peter Howitt. 2005. "Competition and Innovation: An Inverted-U Relationship." The Quarterly Journal of Economics 120(2): 701-28.

Albring, Susan, Monica Banyi, Dan Dhaliwal, and Raynolde Pereira. 2016. "Does the Firm Information Environment Influence Financing Decisions? A Test Using Disclosure Regulation.” Management Science 62(2): 456-78.

Ali, Ashiq, Sandy Klasa, and Eric Yeung. 2014. "Industry Concentration and Corporate Disclosure Policy." Journal of Accounting and Economics 58(2-3): 240-64.

Bamber, Linda Smith, and Youngsoon Susan Cheon. 1998. "Discretionary Management Earnings Forecast Disclosures: Antecedents and Outcomes Associated with Forecast Venue and Forecast Specificity Choices." Journal of Accounting Research 36(2): 167-90.

Beneish, Messod D., and Mark E. Vargus. 2002. "Insider Trading, Earnings Quality, and Accrual Mispricing." The Accounting Review 77(4): 755-91.

Bernard, Darren. 2016. "Is the Risk of Product Market Predation a Cost of Disclosure?" Journal of Accounting and Economics 62(2-3): 305-25.

Bettis, J. C, J. L Coles, and M. L Lemmon. 2000. "Corporate Policies Restricting Trading by Insiders." Journal of Financial Economics 57(2): 191-220.

Bhattacharya, Utpal. 2014. "Insider trading controversies: A literature review." Annual Review of Financial Economics 6: 385-403.

Billings, Mary Brooke, and Matthew C. Cedergren. 2015. "Strategic Silence, Insider Selling and Litigation Risk." Journal of Accounting and Economics 59(2-3): 119-42.

Bloom, Nicholas, Mark Schankerman, and John Van Reenen. 2013. "Identifying Technology Spillovers and Product Market Rivalry." Econometrica 81(4): 1347-93.

Botosan, Christine A., and Mary Stanford. 2005. "Managers' Motives to Withhold Segment Disclosures and the Effect of SFAS No. 131 on Analysts' Information Environment." The Accounting Review 80(3): 751-72.

Brochet, Francois. 2010. "Information Content of Insider Trades before and after the SarbanesOxley Act.” The Accounting Review 85(2): 419-46.

Brown, Stephen, Stephen A. Hillegeist, and Kin Lo. 2004. "Conference Calls and Information Asymmetry." Journal of Accounting and Economics 37(3):343-66.

Carhart, Mark M. 1997. "On Persistence in Mutual Fund Performance." The Journal of Finance 52(1): 57-82.

Chang, Xin, Kangkang Fu, Angie Low, and Wenrui Zhang. 2015. "Non-Executive Employee Stock Options and Corporate Innovation." Journal of Financial Economics 115(1): 168-88.

Chen, Huaizhi, Lauren Cohen, Umit Gurun, Dong Lou, and Christopher Malloy. 2018. "IQ from IP: Simplifying Search in Portfolio Choice.” Harvard Business School working paper. 
Cheng, C. S. Agnes, Henry He Huang, and Yinghua Li. 2016. "Does Shareholder Litigation Deter Insider Trading?" Journal of Law, Finance, and Accounting 1(2): 275-318.

Cheng, Qiang, and Kin Lo. 2006. "Insider Trading and Voluntary Disclosures." Journal of Accounting Research 44(5): 815-48.

Choi, Lyungmae, Lucile Faurel, and Stephen A. Hillegeist. 2019. "Insider Trading, Future Earnings and Post-Earnings Announcement Drift.” Working Paper.

Cohen, Lauren, Christopher Malloy, and Lukasz Pomorski. 2012. "Decoding Inside Information." The Journal of Finance 67(3): 1009-43.

Dai, Lili, Renhui Fu, Jun-Koo Kang, and Inmoo Lee. 2016. "Corporate Governance and the Profitability of Insider Trading." Journal of Corporate Finance 40: 235-53.

Dai, Lili, Jerry T. Parwada, and Bohui Zhang. 2015. "The Governance Effect of the Media's News Dissemination Role: Evidence from Insider Trading: Governance Effect of the Media's News Dissemination Role." Journal of Accounting Research 53(2): 331-66.

Damodaran, Aswath, and Crocker H. Liu. 1993. "Insider Trading as a Signal of Private Information." The Review of Financial Studies 6(1): 79-119.

Darrough, Masako N, and Neal M Stoughton. 1990. "Financial Disclosure Policy in an Entry Game." Journal of Accounting and Economics 12(1-3): 219-43.

Dechow, Patricia M., Alastair Lawrence, and James P. Ryans. 2016. "SEC Comment Letters and Insider Sales." The Accounting Review 91(2): 401-39.

Dye, Ronald A. 1986. "Proprietary and Nonproprietary Disclosures." The Journal of Business 59(2): 331-66.

Ellis, Jesse A., C. Edward Fee, and Shawn E. Thomas. 2012. "Proprietary Costs and the Disclosure of Information About Customers." Journal of Accounting Research 50(3): 685-727.

Frankel, Richard, S.P. Kothari, and Joseph Weber. 2006. "Determinants of the Informativeness of Analyst Research.” Journal of Accounting and Economics 41(1-2): 29-54.

Frankel, Richard, and Xu Li. 2004. "Characteristics of a firm's information environment and the information asymmetry between insiders and outsiders." Journal of Accounting and Economics 37(2): 229-259.

Fresard, Laurent. 2010. "Financial Strength and Product Market Behavior: The Real Effects of Corporate Cash Holdings." The Journal of Finance 65(3): 1097-1122.

Frésard, Laurent, and Philip Valta. 2016. "How Does Corporate Investment Respond to Increased Entry Threat?" Review of Corporate Finance Studies 5(1): 1-35.

Gao, Feng, Ling Lei Lisic, and Ivy Xiying Zhang. 2014. "Commitment to Social Good and Insider Trading." Journal of Accounting and Economics 57(2-3): 149-75.

Graham, John R., Campbell R. Harvey, and Shiva Rajgopal. 2005. "The Economic Implications of Corporate Financial Reporting." Journal of Accounting and Economics 40(1): 3-73.

Griliches, Zvi, Ariel Pakes, and Bronwyn Hall. 1987. "The Value of Patents as Indicators of Inventive Activity.” In Economic Policy and Technological Performance, 97-124.

He, Jie (Jack), and Xuan Tian. 2013. "The Dark Side of Analyst Coverage: The Case of Innovation." Journal of Financial Economics 109(3): 856-78. 
Hoberg, Gerard, and Gordon Phillips. 2016. "Text-Based Network Industries and Endogenous Product Differentiation.” Journal of Political Economy 124(5): 1423-65.

Huang, Ying, Ross Jennings, and Yong Yu. 2017. "Product Market Competition and Managerial Disclosure of Earnings Forecasts: Evidence from Import Tariff Rate Reductions." The Accounting Review 92(3): 185-207.

Huddart, Steven, Bin Ke, and Charles Shi. 2007. "Jeopardy, Non-Public Information, and Insider Trading around SEC 10-K and 10-Q Filings." Journal of Accounting and Economics 43(1): 336.

Jaffe, Adam B. 1986. "Technological Opportunity and Spillovers of R\&D: Evidence from Firms' Patents, Profits, and Market Values." American Economic Review 76(5):984-1002.

Jagolinzer, Alan D., David F. Larcker, and Daniel J. Taylor. 2011. "Corporate Governance and the Information Content of Insider Trades: Information Content of Insider Trades." Journal of Accounting Research 49(5): 1249-74.

Jin, Li, and S.P. Kothari. 2008. "Effect of Personal Taxes on Managers' Decisions to Sell Their Stock." Journal of Accounting and Economics 46(1): 23-46.

Johnson, Marilyn F., Karen K. Nelson, and A. C. Pritchard. 2007. "Do the Merits Matter More? The Impact of the Private Securities Litigation Reform Act." Journal of Law, Economics, \& Organization 23(3): 627-52.

Kallunki, Juha-Pekka, Henrik Nilsson, and Jörgen Hellström. 2009. "Why Do Insiders Trade? Evidence Based on Unique Data on Swedish Insiders." Journal of Accounting and Economics 48(1): 37-53.

Ke, Bin, Steven Huddart, and Kathy Petroni. 2003. "What Insiders Know about Future Earnings and How They Use It: Evidence from Insider Trades." Journal of Accounting and Economics 35(3): 315-46.

Kim, Irene, and Douglas J. Skinner. 2012. "Measuring Securities Litigation Risk." Journal of Accounting and Economics 53(1-2): 290-310.

King, Ronald, Grace Pownall, and Gregory Waymire. 1990. "Expectations Adjustment via Timely Management Forecasts: Review, Synthesis, and Suggestions for Future Research.” Journal of Accounting Literature 9: 113-44.

Lakonishok, Josef, and Inmoo Lee. 2001. “Are Insider Trades Informative?” Review of Financial Studies 14(1): 79-111.

Li, Feng, Russell Lundholm, and Michael Minnis. 2013. "A Measure of Competition Based on 10K Filings.” Journal of Accounting Research 51(2): 399-436.

Li, Xi. 2010. "The Impacts of Product Market Competition on the Quantity and Quality of Voluntary Disclosures." Review of Accounting Studies 15(3): 663-711.

Massa, Massimo, Wenlan Qian, Weibiao Xu, and Hong Zhang. 2015. "Competition of the Informed: Does the Presence of Short Sellers Affect Insider Selling?" Journal of Financial Economics 118(2): 268-88.

Meulbroek, Lisa K. 1992. “An Empirical Analysis of Illegal Insider Trading.” The Journal of Finance 47(5): 1661-99. 
Peress, Joel. 2010. "Product Market Competition, Insider Trading, and Stock Market Efficiency." The Journal of Finance 65(1): 1-43.

Petersen, Mitchell A. 2009. "Estimating Standard Errors in Finance Panel Data Sets: Comparing Approaches." Review of Financial Studies 22(1): 435-80.

Piotroski, Joseph D., and Darren T. Roulstone. 2004. "The Influence of Analysts, Institutional Investors, and Insiders on the Incorporation of Market, Industry, and Firm-Specific Information into Stock Prices." Accounting Review 79(4): 1119-51.

Piotroski, Joseph D., and Darren T. Roulstone. 2005. "Do Insider Trades Reflect Both Contrarian Beliefs and Superior Knowledge about Future Cash Flow Realizations?" Journal of Accounting and Economics 39(1): 55-81.

Raith, Michael. 2003. Competition, Risk, and Managerial Incentives." American Economic Review 93(4): 1425-1436.

Ravina, Enrichetta, and Paola Sapienza. 2010. "What Do Independent Directors Know? Evidence from Their Trading." Review of Financial Studies 23(3): 962-1003.

Roulstone, Darren T. 2003. "The Relation between Insider-Trading Restrictions and Executive Compensation." Journal of Accounting Research 41(3): 525-51.

Seyhun, H. Nejat. 1986. "Insiders' Profits, Costs of Trading, and Market Efficiency." Journal of Financial Economics 16(2): 189-212.

Sivakumar, Kumar, and Jayaraman Vijayakumar. 2001. "Insider Trading, Analysts' Forecast Revisions, and Earnings Changes." Journal of Accounting, Auditing \& Finance 16(2): 167-87.

Stocken, Phillip C. 2000. "Credibility of Voluntary Disclosure." The RAND Journal of Economics 31(2): 359.

Valta, Philip. 2012. "Competition and the Cost of Debt." Journal of Financial Economics 105(3): $661-82$.

Verrecchia, Robert E. 1983. "Discretionary Disclosure." Journal of Accounting and Economics 5: $179-94$.

Verrecchia, Robert E. 1990. "Endogenous Proprietary Costs through Firm Interdependence." Journal of Accounting and Economics 12(1-3): 245-50.

Verrecchia, Robert E. 2001. “Essays on Disclosure.” Journal of Accounting and Economics 32(1): 97-180.

Verrecchia, Robert E., and Joseph Weber. 2006. "Redacted Disclosure." Journal of Accounting Research 44(4): 791-814.

Wagenhofer, Alfred. 1990. "Voluntary Disclosure with a Strategic Opponent." Journal of Accounting and Economics 12(4): 341-63.

Wang, Isabel Yanyan. 2007. "Private Earnings Guidance and Its Implications for Disclosure Regulation." The Accounting Review 82(5): 1299-1332.

Wooldridge, Jeffrey M. 2010. Econometric Analysis of Cross Section and Panel Data. Cambridge, Mass: MIT Press.

Xu, Jin. 2012. "Profitability and Capital Structure: Evidence from Import Penetration." Journal of Financial Economics 106(2): 427-46. 


\section{Appendix A Variable Definitions}

\section{Proprietary Cost Measures}

Composite

$R \& D$

Patents

Product Similarity

Tech Similarity

Competition Words

Prop Period

Post Reduction
Sum of the values of $R \& D$, Patents, and Product Similarity, where each measure is standardized to have zero mean and unit variance.

Decile ranking of R\&D expenditures scaled by total sales.

Natural logarithm of one plus the number of patent applications filed during the fiscal year.

Sum of the pairwise product similarities between the firm and all other firms in Compustat in the fiscal year. A firm-by-firm pairwise product similarity score is estimated using the cosine similarity of firms' product spaces based on business descriptions from 10-K filings (see Hoberg and Phillips 2016).

Natural logarithm of sum of the pairwise technological similarities between the firm and all other firms in Compustat . A firm-by-firm pairwise technological similarity score is estimated using the cosine similarity of technology classes (426 different classes) based on patents filed during the period 1986 to 2010 (see Bloom et al. 2013).

Number of competition-related words scaled by total number of words in $10-\mathrm{K}$ filing, where competition-related words include "competition," "competitor," "competitive," "compete," and "competing" (singular and plural). Cases where "not," "less," "few," or "limited" precedes the competition-related word by three or fewer words are excluded (see Li et al. 2013).

Indicator variable equal to one if the firm-year is in a proprietary period, zero otherwise. Proprietary periods are firm-year observations that have at least one product announcement in the subsequent year but no announcement in the current year or one product announcement in the subsequent two years but no announcement in the current year.

Indicator variable equal to one if the industry experiences a tariff rate reduction by the prior calendar year that is larger than three times the median tariff rate reduction in that industry, zero otherwise.

\section{Insider Trading Measures}

Purchases

Alpha

BHAR

BHRaw

\section{Firm Characteristics}

Size

$B M$

BHRaw
Total number of shares purchased by insiders during the fiscal year, scaled by the total number of shares outstanding at the beginning of the year, multiplied by 1,000.

Daily alpha, the intercept from Carhart's (1997) four-factor model, estimated over 360 calendar days.

Buy-and-hold abnormal stock returns estimated using Carhart's (1997) four-factor model, estimated over 360 calendar days.

Buy-and-hold raw stock returns, estimated over 360 calendar days. 
Coverage

InstOwn

Turnover

Litigation

Volatility

TradeSize
Natural logarithm of one plus the number of analysts issuing earnings forecasts.

Number of shares held by institutional investors scaled by total shares outstanding.

Natural logarithm of the ratio of the number of shares traded during the year divided by number of shares outstanding at the beginning of the year.

Predicted litigation probability using Model (3) of Kim and Skinner (2012), which regresses the indicator variable of litigation on industry membership and measures of firm characteristics (including size, growth, stock performance, skewness, volatility, and liquidity).

Variance of daily stock returns over the year.

Dollar value of the daily purchases by an insider scaled by the natural logarithm of the market value of equity of the firm. 


\section{Appendix B \\ Can Litigation Risk be an Alternative Explanation?}

An alternative explanation for the negative association between proprietary costs and insider purchases is that proprietary costs are correlated with litigation risk, and litigation risk is the factor driving insider trading decisions. However, this alternative explanation does not seem plausible in our setting primarily because insiders face little to no litigation or regulatory risk when they purchase their own stock before good news. This is in sharp contrast with insiders facing substantial litigation risk when they sell before bad news. ${ }^{25}$ Indeed, private class action suits on behalf of shareholders occur when shareholders suffer damages sufficiently large to make lawsuits worthwhile. Yet, when insiders purchase shares based on private information, shareholders do not suffer damages. Consistent with this argument, Cohen et al. (2012) find opportunistic insider sales significantly increase the probability of being investigated by the SEC, but opportunistic insider purchases do not. Thus, insiders face minimal legal risk, if any at all, when they exploit their private information by purchasing their own stock.

While litigation risk does not seem plausibly related to insider purchase decisions, we still include the ex ante litigation risk measure from Kim and Skinner (2012), Litigation, as a control variable in our tests. This variable fails to be significantly negative in any of our specifications, which is consistent with our argument above.

One could argue that the influence of litigation risk on the association between proprietary costs and insider purchases varies non-linearly, and thus, including Litigation in the regressions is insufficient to control for this potential association. To address this concern, we divide firm-year

\footnotetext{
${ }^{25}$ For example, Johnson et al. (2007) find litigation increases after abnormal insider sales, especially after the Private Securities Litigation Reform Act of 1995, and Billings and Cedergren (2015) find the probability of being sued significantly increases when insiders engage in sales prior to the announcement of negative earnings news and fail to provide prior warnings.
} 
observations into litigation risk terciles based on industry-year cutoff points and estimate Equation (1) within each tercile. The results are presented in Table A1 below. The results show that within each tercile of litigation risk, the association between proprietary costs and insider purchases is negative and significant (estimated coefficients range from -0.116 to -0.204 , with $t$-statistics ranging from -2.18 to -2.72 ). Overall, these results provide further evidence that our results are not driven by litigation risk.

Table A1

Proprietary Costs and Insider Purchases, by Litigation Risk Tercile

\begin{tabular}{|c|c|c|c|}
\hline \multirow{3}{*}{ Variable } & \multicolumn{3}{|c|}{$\begin{array}{l}\text { Coefficient } \\
(t \text {-statistic) }\end{array}$} \\
\hline & \multicolumn{3}{|c|}{ Litigation Risk } \\
\hline & $\begin{array}{l}\text { Lowest } \\
\text { (1) }\end{array}$ & (2) & $\begin{array}{l}\text { Highest } \\
\text { (3) }\end{array}$ \\
\hline Composite & $\begin{array}{l}-0.204 \text { *** } \\
(-2.72)\end{array}$ & $\begin{array}{l}-0.147 \text { *** } \\
(-2.61)\end{array}$ & $\begin{array}{l}-0.116 * * \\
(-2.18)\end{array}$ \\
\hline Control Variables & & Included & \\
\hline Year Fixed Effects & & Included & \\
\hline Industry Fixed Effects & & Included & \\
\hline Observations & 21,379 & 21,144 & 20,893 \\
\hline Pseudo $R^{2}(\%)$ & 2.42 & 3.32 & 2.98 \\
\hline
\end{tabular}

Notes: This table presents the results from tobit regressions of insider purchases on proprietary costs by litigation risk tercile. Standard errors are clustered by firm and year. $* * *, * *$, and * represent statistical significance at $p<0.01, p<$ 0.05 , and $p<0.10$ (two-tailed), respectively. The sample covers calendar years 1986 to 2017. Firm-year observations are classified into low to high litigation risk terciles based on industry-year cutoff points and using predicted litigation probability from Kim and Skinner (2012). The dependent variable is Purchases, the number of shares purchased by insiders during the year scaled by total number of shares outstanding at the beginning of the year. Industry grouping is defined based on the Fama-French (1997) 48-industry classification. Composite is a composite measure of proprietary costs, defined as the sum of the values of $R \& D$, Patents, and Product Similarity, where each measure is standardized to have zero mean and unit variance. See Appendix A for additional variable definitions. All continuous variables are winsorized at $1 \%$ and $99 \%$. 
Table 1

Sample Selection

\section{Sample Selection Criteria for Firm-Years}

Number of Number of

Firm-Years Distinct Firms

All firm-year observations from Compustat with fiscal year end between December 31, 1986 and December 31, 2017

292,710

28,839

Less missing required data to construct control variables and industry classification (based on the Fama-French (1997) 48-industry classification).

Final samples when:

$\begin{array}{lrr}\text { Prop Cost }=\text { Composite } & 63,416 & 9,127 \\ \text { Prop Cost }=R \& D & 133,692 & 14,477 \\ \text { Prop Cost }=\text { Patents } & 115,472 & 13,500 \\ \text { Prop Cost }=\text { Product Similarity } & 77,777 & 9,731 \\ \text { Prop Cost }=\text { Tech Similarity } & 50,604 & 4,602 \\ \text { Prop Cost }=\text { Competition Words } & 68,128 & 9,130\end{array}$

\section{Sample Selection Criteria for Insider Purchases}

\section{Number of Number of Transactions Distinct Firms}

All insider purchase transactions completed by top 5 executives (i.e., CEO, CFO, COO, President, and Chairman of Board) during sample period January 1, 321,733 16,761 1986 to December 31, 2017

Less transactions without sufficient level of accuracy and reasonableness (i.e., TFN Cleanse Indicator is not ' $S$ ' or 'A')

Less transactions without required data to construct control variables

Less transactions with missing stock return data 
Table 2

Descriptive Statistics and Correlation Coefficients

Panel A: Descriptive Statistics

Q1 Mean Median Q3 Std.Dev.

Proprietary Cost Measures

Composite

$-1.500$

0.009

$-0.878$

1.219

1.838

$R \& D$

0.111

0.328

0.111

0.556

0.325

Patents

0.000

0.432

0.000

0.000

0.996

Product Similarity

1.315

9.715

2.388

6.479

18.337

Tech Similarity

4.088

4.604

4.737

5.261

0.900

Competition Words

0.365

0.650

0.577

0.862

0.388

Insider Purchases

$$
\text { Purchases }
$$

0.000

0.490

0.000

0.000

2.688

$\underline{\text { Firm Characteristics }}$

\begin{tabular}{lccccc} 
Size & 3.841 & 5.534 & 5.456 & 7.150 & 2.307 \\
BM & 0.309 & 0.675 & 0.550 & 0.876 & 0.775 \\
BHRaw & -0.206 & 0.154 & 0.064 & 0.350 & 0.657 \\
Coverage & 0.000 & 1.192 & 1.099 & 2.303 & 1.192 \\
InstOwn & 0.037 & 0.356 & 0.289 & 0.629 & 0.321 \\
Turnover & -0.941 & -0.202 & -0.137 & 0.613 & 1.142 \\
Litigation & 0.069 & 0.288 & 0.174 & 0.423 & 0.285 \\
Volatility & 0.019 & 0.035 & 0.029 & 0.044 & 0.022 \\
\hline
\end{tabular}


Panel B: Pearson Correlations (Below the Diagonal) and Spearman Correlations (Above the Diagonal)

\begin{tabular}{|c|c|c|c|c|c|c|c|c|c|c|c|c|c|c|c|c|}
\hline & & (1) & (2) & (3) & (4) & (5) & (6) & (7) & (8) & (9) & (10) & (11) & (12) & (13) & (14) & (15) \\
\hline (1) & Composite & 1.000 & 0.685 & 0.585 & 0.472 & 0.518 & 0.159 & 0.004 & 0.080 & -0.174 & -0.016 & 0.124 & 0.049 & 0.102 & 0.106 & 0.028 \\
\hline (2) & $R \& D$ & 0.695 & 1.000 & 0.494 & -0.076 & 0.438 & 0.369 & -0.027 & -0.030 & -0.244 & $-\mathbf{0 . 0 3 7}$ & 0.010 & 0.067 & 0.231 & 0.177 & 0.241 \\
\hline (3) & Patents & 0.699 & 0.390 & 1.000 & -0.058 & 0.340 & 0.156 & -0.052 & 0.252 & -0.171 & 0.017 & 0.232 & 0.207 & 0.186 & 0.127 & -0.045 \\
\hline$(4)$ & Product Similarity & 0.429 & -0.129 & -0.116 & 1.000 & 0.403 & -0.119 & 0.042 & 0.064 & 0.054 & 0.007 & 0.117 & -0.088 & -0.020 & 0.016 & -0.101 \\
\hline$(5)$ & Tech Similarity & 0.504 & 0.431 & 0.344 & 0.301 & 1.000 & 0.129 & -0.057 & 0.230 & -0.240 & 0.008 & 0.200 & 0.061 & 0.241 & 0.229 & 0.021 \\
\hline$(6)$ & Competition Words & 0.190 & 0.365 & 0.121 & -0.167 & 0.122 & 1.000 & -0.014 & -0.130 & -0.104 & -0.051 & -0.050 & 0.125 & 0.124 & 0.099 & 0.218 \\
\hline (7) & Purchases & -0.045 & -0.012 & -0.050 & -0.013 & -0.053 & -0.009 & 1.000 & -0.133 & 0.069 & -0.094 & -0.090 & -0.009 & -0.043 & -0.049 & 0.075 \\
\hline$(8)$ & Size & 0.108 & -0.051 & 0.340 & -0.092 & 0.231 & -0.121 & -0.142 & 1.000 & -0.321 & 0.038 & 0.715 & 0.417 & 0.441 & 0.249 & -0.564 \\
\hline & $B M$ & -0.129 & -0.151 & -0.110 & 0.073 & -0.160 & -0.051 & 0.0 & -0.269 & 1.000 & 0.107 & -0.241 & -0.150 & -0.276 & -0.151 & 0.039 \\
\hline (10) & BHRaw & 0.011 & 0.025 & 0.012 & -0.011 & 0.023 & 0.010 & -0.008 & -0.075 & 0.105 & 1.000 & 0.089 & 0.089 & -0.072 & -0.030 & -0.069 \\
\hline (11) & Coverage & 0.129 & 0.003 & 0.289 & -0.055 & 0.186 & -0.047 & -0.108 & 0.702 & -0.185 & 0.022 & 1.000 & 0.506 & 0.446 & 0.245 & -0.348 \\
\hline (12) & InstOwn & 0.051 & 0.039 & 0.208 & -0.166 & 0.070 & 0.089 & -0.090 & 0.466 & -0.144 & 0.041 & 0.552 & 1.000 & 0.366 & 0.114 & -0.216 \\
\hline (13) & Turnover & 0.122 & 0.238 & 0.182 & -0.257 & 0.229 & 0.121 & -0.043 & 0.418 & -0.187 & -0.048 & 0.443 & 0.415 & 1.000 & 0.447 & 0.121 \\
\hline (14) & Litigation & 0.136 & 0.195 & 0.109 & -0.132 & 0.180 & 0.118 & -0.004 & 0.116 & -0.071 & 0.022 & 0.129 & 0.048 & 0.365 & 1.000 & 0.291 \\
\hline (15) & Volatility & 0.043 & 0.225 & -0.100 & -0.127 & 0.016 & 0.165 & 0.111 & -0.536 & 0.106 & 0.103 & -0.345 & -0.281 & 0.066 & 0.315 & 1.000 \\
\hline
\end{tabular}

Notes: Panel A presents selected descriptive statistics. Panel B presents Pearson (Spearman) correlation coefficients below (above) the diagonal. The sample covers the period 1986 to 2017. Proprietary costs are estimated using five individual measures, R\&D, Patents, Product Similarity, Tech Similarity, and Competition Words, and a composite measure, Composite. Composite is the sum of the values of the five individual measures, where each measure is standardized to have zero mean and unit variance. See Appendix A for additional variable definitions. All continuous variables are winsorized at $1 \%$ and $99 \%$. 


\section{Table 3}

\section{Proprietary Costs and Insider Purchases}

$$
\begin{aligned}
\text { Purchases }_{i, t}=\alpha & +\beta_{1} \text { Prop Cost }_{i, t-1}+\beta_{2} \text { Size }_{i, t-1}+\beta_{3} \text { BM }_{i, t-1}+\beta_{4} \text { BHRaw }_{i, t-1}+\beta_{5} \text { Coverage }_{i, t-1}+\beta_{6} \text { InstOwn }_{i, t-1} \\
& +\beta_{7} \text { Turnover }_{i, t-1}+\beta_{8} \text { Litigation }_{i, t-1}+\beta_{9} \text { Volatility }_{i, t-1}+\sum \gamma_{j} \text { Industry }_{j}+\sum \delta_{t} \text { Year }_{t}+\varepsilon_{i, t}
\end{aligned}
$$

\begin{tabular}{|c|c|c|c|c|c|c|}
\hline \multirow{4}{*}{ Variable } & \multicolumn{6}{|c|}{$\begin{array}{l}\text { Coefficient } \\
(t \text {-statistic })\end{array}$} \\
\hline & \multicolumn{6}{|c|}{ Prop Cost $=$} \\
\hline & Composite & $R \& D$ & Patents & $\begin{array}{c}\text { Product } \\
\text { Similarity }\end{array}$ & $\begin{array}{c}\text { Tech } \\
\text { Similarity }\end{array}$ & $\begin{array}{c}\text { Competition } \\
\text { Words }\end{array}$ \\
\hline & (1) & (2) & (3) & (4) & (5) & (6) \\
\hline Prop Cost & $\begin{array}{l}-0.157 \text { *** } \\
(-3.52)\end{array}$ & $\begin{array}{l}-0.672 \text { *** } \\
(-3.21)\end{array}$ & $\begin{array}{l}-0.133 * * \\
(-2.02)\end{array}$ & $\begin{array}{l}-0.016 \text { *** } \\
(-2.77)\end{array}$ & $\begin{array}{l}-0.228 * * * \\
(-2.59)\end{array}$ & $\begin{array}{l}-0.429 \text { ** } \\
(-2.55)\end{array}$ \\
\hline Size & $\begin{array}{l}-0.651 \text { *** } \\
(-11.26)\end{array}$ & $\begin{array}{l}-1.006 * * * \\
(-12.96)\end{array}$ & $\begin{array}{l}-0.982 \text { *** } \\
(-11.58)\end{array}$ & $\begin{array}{l}-0.720 \text { *** } \\
(-11.23)\end{array}$ & $\begin{array}{l}-1.041 \text { **** } \\
(-10.71)\end{array}$ & $\begin{array}{l}-0.713 * * * \\
(-10.46)\end{array}$ \\
\hline$B M$ & $\begin{array}{l}0.224 * * * \\
(2.70)\end{array}$ & $\begin{array}{c}0.033 \\
(0.53)\end{array}$ & $\begin{array}{l}0.115 * \\
(1.72)\end{array}$ & $\begin{array}{l}0.154 \text { ** } \\
(2.02)\end{array}$ & $\begin{array}{l}0.203 * * \\
(2.33)\end{array}$ & $\begin{array}{l}0.106 \\
(1.22)\end{array}$ \\
\hline BHRaw & $\begin{array}{l}-0.734 * * * \\
(-4.04)\end{array}$ & $\begin{array}{l}-0.827 * * * \\
(-6.19)\end{array}$ & $\begin{array}{l}-0.774 * * * \\
(-5.70)\end{array}$ & $\begin{array}{l}-0.761 * * * \\
(-4.33)\end{array}$ & $\begin{array}{l}-0.787 * * * \\
(-4.73)\end{array}$ & $\begin{array}{l}-0.792 * * * \\
(-4.78)\end{array}$ \\
\hline Coverage & $\begin{array}{l}0.097 \\
(1.50)\end{array}$ & $\begin{array}{l}0.207 * * * \\
(3.53)\end{array}$ & $\begin{array}{l}0.227 \text { *** } \\
(3.44)\end{array}$ & $\begin{array}{l}0.070 \\
(1.23)\end{array}$ & $\begin{array}{l}0.270 \text { *** } \\
(3.25)\end{array}$ & $\begin{array}{l}0.095 * \\
(1.80)\end{array}$ \\
\hline InstOwn & $\begin{array}{l}-1.603 * * * \\
(-3.97)\end{array}$ & $\begin{array}{l}0.970 * * * \\
(4.85)\end{array}$ & $\begin{array}{l}0.839 \text { *** } \\
(3.85)\end{array}$ & $\begin{array}{l}-1.108 * * * \\
(-2.98)\end{array}$ & $\begin{array}{l}0.881 \text { *** } \\
(3.19)\end{array}$ & $\begin{array}{l}-1.059 * * * \\
(-3.47)\end{array}$ \\
\hline Turnover & $\begin{array}{l}0.112 \\
(1.48)\end{array}$ & $\begin{array}{l}0.121 * \\
(1.85)\end{array}$ & $\begin{array}{l}0.143 * * \\
(2.06)\end{array}$ & $\begin{array}{l}0.077 \\
(1.10)\end{array}$ & $\begin{array}{l}0.109 \\
(1.30)\end{array}$ & $\begin{array}{l}0.085 \\
(1.31)\end{array}$ \\
\hline Litigation & $\begin{array}{l}0.578 * * * \\
(3.77)\end{array}$ & $\begin{array}{c}0.032 \\
(0.17)\end{array}$ & $\begin{array}{l}-0.050 \\
(-0.24)\end{array}$ & $\begin{array}{l}0.529 * * * \\
(3.88)\end{array}$ & $\begin{array}{l}0.250 \\
(1.06)\end{array}$ & $\begin{array}{l}0.499 \text { *** } \\
(3.34)\end{array}$ \\
\hline Volatility & $\begin{array}{l}5.539 \\
(1.20)\end{array}$ & $\begin{array}{l}-0.257 \\
(-0.07)\end{array}$ & $\begin{array}{l}-0.422 \\
(-0.11)\end{array}$ & $\begin{array}{c}3.174 \\
(0.74)\end{array}$ & $\begin{array}{l}5.355 \\
(1.14)\end{array}$ & $\begin{array}{l}6.023 * \\
(1.73)\end{array}$ \\
\hline Year Fixed Effects & \multicolumn{6}{|c|}{ Included } \\
\hline Industry Fixed Effects & \multicolumn{6}{|c|}{ Included } \\
\hline Observations & 63,416 & 133,692 & 115,472 & 77,777 & 50,604 & 68,128 \\
\hline Pseudo R ${ }^{2}(\%)$ & 2.72 & 3.09 & 2.85 & 3.04 & 3.82 & 3.38 \\
\hline
\end{tabular}

\section{Panel A: All Purchases}


Table 3 (cont'd)

Panel B: Opportunistic versus Routine Purchases

\begin{tabular}{|c|c|c|c|c|c|c|}
\hline \multirow{5}{*}{ Variable } & \multicolumn{6}{|c|}{$\begin{array}{l}\text { Coefficient } \\
(t \text {-statistic) }\end{array}$} \\
\hline & \multicolumn{6}{|c|}{ Prop Cost $=$} \\
\hline & \multicolumn{2}{|c|}{ Composite } & \multicolumn{2}{|c|}{$R \& D$} & \multicolumn{2}{|c|}{ Patents } \\
\hline & $\begin{array}{c}\text { Opportunistic } \\
\text { Purchases }\end{array}$ & $\begin{array}{c}\text { Routine } \\
\text { Purchases }\end{array}$ & $\begin{array}{c}\text { Opportunistic } \\
\text { Purchases } \\
\end{array}$ & $\begin{array}{c}\text { Routine } \\
\text { Purchases }\end{array}$ & $\begin{array}{c}\text { Opportunistic } \\
\text { Purchases }\end{array}$ & $\begin{array}{c}\text { Routine } \\
\text { Purchases }\end{array}$ \\
\hline & (1) & (2) & (3) & (4) & (5) & (6) \\
\hline Prop Cost & $\begin{array}{l}-0.047 * * * \\
(-3.55)\end{array}$ & $\begin{array}{l}-0.024 * \\
(-1.79)\end{array}$ & $\begin{array}{l}-0.127 * * \\
(-2.08)\end{array}$ & $\begin{array}{l}-0.092 \\
(-1.30)\end{array}$ & $\begin{array}{l}-0.045 * * * \\
(-2.79)\end{array}$ & $\begin{array}{l}-0.011 \\
(-0.55)\end{array}$ \\
\hline $\begin{array}{c}p \text {-value for the test of } \\
\text { equal coefficients on } \\
\text { Prop Cost }\end{array}$ & \multicolumn{2}{|c|}{$\begin{array}{l}\text { (1) vs. (2) } \\
0.06\end{array}$} & \multicolumn{2}{|c|}{$\begin{array}{l}\text { (3) vs. (4) } \\
0.54\end{array}$} & \multicolumn{2}{|c|}{$\begin{array}{l}\text { (5) vs. (6) } \\
0.06\end{array}$} \\
\hline $\begin{array}{l}\text { Control Variables } \\
\text { Year Fixed Effects } \\
\text { Industry Fixed Effects }\end{array}$ & \multicolumn{6}{|c|}{$\begin{array}{l}\text { Included } \\
\text { Included }\end{array}$} \\
\hline Observations & 51,689 & 51,689 & 106,165 & 106,165 & 89,937 & 89,937 \\
\hline Pseudo R $(\%)$ & 4.98 & 5.55 & 6.74 & 11.84 & 6.35 & 12.79 \\
\hline \multicolumn{7}{|c|}{ Panel B: Opportunistic versus Routine Purchases (continued) } \\
\hline \multicolumn{7}{|c|}{$\begin{array}{l}\text { Coefficient } \\
(t \text {-statistic) }\end{array}$} \\
\hline \multirow{4}{*}{ Variable } & \multicolumn{6}{|c|}{ Prop Cost $=$} \\
\hline & \multicolumn{2}{|c|}{ Product Similarity } & \multicolumn{2}{|c|}{ Tech Similarity } & \multicolumn{2}{|c|}{ Competition Words } \\
\hline & $\begin{array}{l}\text { Opportunistic } \\
\text { Purchases }\end{array}$ & $\begin{array}{c}\text { Routine } \\
\text { Purchases }\end{array}$ & $\begin{array}{l}\text { Opportunistic } \\
\text { Purchases }\end{array}$ & $\begin{array}{c}\text { Routine } \\
\text { Purchases }\end{array}$ & $\begin{array}{l}\text { Opportunistic } \\
\text { Purchases }\end{array}$ & $\begin{array}{l}\text { Routine } \\
\text { Purchases }\end{array}$ \\
\hline & $(7)$ & $(8)$ & $(9)$ & $(10)$ & $(11)$ & $(12)$ \\
\hline Prop Cost & $\begin{array}{l}-0.004 * * * \\
(-2.87)\end{array}$ & $\begin{array}{l}-0.002 \\
(-1.47)\end{array}$ & $\begin{array}{l}-0.100 * * * \\
(-2.97)\end{array}$ & $\begin{array}{l}-0.001 \\
(-0.04)\end{array}$ & $\begin{array}{l}-0.057 \\
(-1.51)\end{array}$ & $\begin{array}{l}0.016 \\
(0.46)\end{array}$ \\
\hline $\begin{array}{c}p \text {-value for the test of } \\
\text { equal coefficients on } \\
\text { Prop Cost }\end{array}$ & \multicolumn{2}{|c|}{$\begin{array}{l}\text { (7) vs. (8) } \\
0.06\end{array}$} & \multicolumn{2}{|c|}{$\begin{array}{l}\text { (9) vs. (10) } \\
<0.01\end{array}$} & \multicolumn{2}{|c|}{$\begin{array}{l}\text { (11) vs. (12) } \\
0.04\end{array}$} \\
\hline Control Variables & \multicolumn{6}{|c|}{ Included } \\
\hline Year Fixed Effects & \multirow{2}{*}{\multicolumn{6}{|c|}{$\begin{array}{l}\text { Included } \\
\text { Included }\end{array}$}} \\
\hline Industry Fixed Effects & & & & & & \\
\hline Observations & 64,231 & 64,231 & 39,915 & 39,915 & 56,375 & 56,375 \\
\hline Pseudo R²(\%) & 5.72 & 5.47 & 7.48 & 11.64 & 6.55 & 6.58 \\
\hline
\end{tabular}

Notes: This table presents the results from tobit regressions of insider purchases on proprietary costs. Standard errors are clustered by firm and year. $* * *, * *$, and * represent statistical significance at $p<0.01, p<0.05$, and $p<0.10$ (twotailed), respectively. The sample covers the period 1986 to 2017. In Panel A, the dependent variable is Purchases, the number of shares purchased by insiders during the year scaled by total number of shares outstanding at the beginning of the year. In Panels B and C, the dependent variable is the number of opportunistic (routine) purchases in Columns (1), (3), and (5) (Columns (2), (4), and (6)) during the year scaled by total number of shares outstanding at the beginning of the year. Insider purchases are classified as opportunistic or routine based on insiders' trading patterns in the three preceding years. If an insider trades in the same calendar month in three consecutive years, then all subsequent trades by this insider are classified as routine. If an insider trades in three consecutive years but no trades are made in the same calendar month, then all subsequent trades by this insider are classified as opportunistic. Proprietary costs are estimated using five individual measures, $R \& D$, Patents, Product Similarity, Tech Similarity, and Competition Words, and a composite measure, Composite. Composite is the sum of the values of R\&D, Patents, and Product Similarity, where each measure is standardized to have zero mean and unit variance. See Appendix A for additional variable definitions. All continuous variables are winsorized at $1 \%$ and $99 \%$. 
Table 4

Proprietary Costs and Insider Purchase Profits Profit $_{k, i, d, t}=\alpha+\beta_{1}$ Composite $_{i, t-1}+\beta_{2}$ Size $_{i, t-1}+\beta_{3}$ BM $_{i, t-1}+\beta_{4}$ BHRaw $_{i,[-380 ;-20]}+\beta_{5}$ Coverage $_{i, t-1}+\beta_{6}$ InstOwn $_{i, t-1}$
$+\beta_{7}$ Turnover $_{i,-380 ;-20]}+\beta_{8}$ Volatility $_{i,-380 ;-20]}+\beta_{9}$ TradeSize $_{k, i, d, t}+\sum \gamma_{j}$ Industry $_{j}+\sum \delta_{t}$ Year $_{t}+\varepsilon_{k, i, d, t}$

Panel A: All Purchases

\begin{tabular}{|c|c|c|c|}
\hline \multirow{4}{*}{ Variable } & \multicolumn{3}{|c|}{$\begin{array}{l}\text { Coefficient } \\
(t \text {-statistic })\end{array}$} \\
\hline & \multicolumn{3}{|c|}{ Profit $=$} \\
\hline & Alpha & BHAR & BHRaw \\
\hline & $(1)$ & $(2)$ & (3) \\
\hline Composite & $\begin{array}{l}0.009 * * * \\
(3.27)\end{array}$ & $\begin{array}{l}0.033 \text { *** } \\
(2.86)\end{array}$ & $\begin{array}{l}0.031 * * * \\
(2.87)\end{array}$ \\
\hline Size & $\begin{array}{l}-0.026 * * * \\
(-3.87)\end{array}$ & $\begin{array}{l}-0.060 * * * \\
(-2.83)\end{array}$ & $\begin{array}{l}-0.048 * * \\
(-2.26)\end{array}$ \\
\hline$B M$ & $\begin{array}{l}0.005 \\
(1.49)\end{array}$ & $\begin{array}{l}0.050 * * * \\
(2.72)\end{array}$ & $\begin{array}{l}0.040 * * \\
(2.41)\end{array}$ \\
\hline BHRaw $w_{[-380,-20]}$ & $\begin{array}{l}0.020 \text { *** } \\
(5.69)\end{array}$ & $\begin{array}{l}0.060 \text { *** } \\
(3.64)\end{array}$ & $\begin{array}{l}0.070 * * * \\
(4.02)\end{array}$ \\
\hline Coverage & $\begin{array}{l}0.048 * * \\
(2.21)\end{array}$ & $\begin{array}{l}0.227 \text { *** } \\
(3.36)\end{array}$ & $\begin{array}{l}0.261 \text { *** } \\
(3.49)\end{array}$ \\
\hline InstOwn & $\begin{array}{l}-0.027 * * * \\
(-4.97)\end{array}$ & $\begin{array}{l}-0.051 * * \\
(-2.22)\end{array}$ & $\begin{array}{l}-0.050 * \\
(-1.76)\end{array}$ \\
\hline Turnover $[-380,-20]$ & $\begin{array}{l}-0.023 * * * \\
(-3.46)\end{array}$ & $\begin{array}{l}-0.028 \\
(-1.17)\end{array}$ & $\begin{array}{l}-0.015 \\
(-0.45)\end{array}$ \\
\hline Volatility $_{[-380,-20]}$ & $\begin{array}{l}2.416 * * * \\
(3.29)\end{array}$ & $\begin{array}{l}2.718 * * \\
(2.03)\end{array}$ & $\begin{array}{l}2.784 * \\
(1.66)\end{array}$ \\
\hline Trade Size & $\begin{array}{l}0.000 \\
(1.52)\end{array}$ & $\begin{array}{l}0.001 \\
(0.94)\end{array}$ & $\begin{array}{l}-0.001 \\
(-1.31)\end{array}$ \\
\hline Year Fixed Effects & & Included & \\
\hline Industry Fixed Effects & & Included & \\
\hline Observations & 62,899 & 63,961 & 63,816 \\
\hline Adjusted R ${ }^{2}(\%)$ & 17.60 & 5.60 & 12.35 \\
\hline
\end{tabular}

Panel B: Opportunistic versus Routine Purchases

\begin{tabular}{|c|c|c|c|c|c|c|}
\hline \multirow{5}{*}{ Variable } & \multicolumn{6}{|c|}{$\begin{array}{l}\text { Coefficient } \\
(t \text {-statistic })\end{array}$} \\
\hline & \multicolumn{6}{|c|}{ Profit $=$} \\
\hline & \multicolumn{2}{|c|}{ Alpha } & \multicolumn{2}{|c|}{ BHAR } & \multicolumn{2}{|c|}{ BHRaw } \\
\hline & $\begin{array}{l}\text { Opportunistic } \\
\text { Purchases }\end{array}$ & $\begin{array}{c}\text { Routine } \\
\text { Purchases }\end{array}$ & $\begin{array}{l}\text { Opportunistic } \\
\text { Purchases }\end{array}$ & $\begin{array}{c}\text { Routine } \\
\text { Purchases }\end{array}$ & $\begin{array}{c}\text { Opportunistic } \\
\text { Purchases }\end{array}$ & $\begin{array}{c}\text { Routine } \\
\text { Purchases }\end{array}$ \\
\hline & $(1)$ & $(2)$ & $(3)$ & $(4)$ & $(5)$ & (6) \\
\hline Composite & $\begin{array}{l}0.017 * * \\
(2.37)\end{array}$ & $\begin{array}{l}0.010 \\
(1.45)\end{array}$ & $\begin{array}{l}0.074 * * \\
(2.35)\end{array}$ & $\begin{array}{l}0.040 * * * \\
(2.59)\end{array}$ & $\begin{array}{l}0.069 * * \\
(2.22)\end{array}$ & $\begin{array}{l}0.038 * \\
(1.77)\end{array}$ \\
\hline $\begin{array}{c}p \text {-value for the test of } \\
\text { equal coefficients on } \\
\text { Composite }\end{array}$ & \multicolumn{2}{|c|}{$\begin{array}{l}\text { (1) vs. (2) } \\
<0.01\end{array}$} & \multicolumn{2}{|c|}{$\begin{array}{l}\text { (3) vs. (4) } \\
<0.01\end{array}$} & \multicolumn{2}{|c|}{$\begin{array}{l}\text { (5) vs. (6) } \\
<0.01\end{array}$} \\
\hline Control Variables & \multicolumn{6}{|c|}{ Included } \\
\hline Year Fixed Effects & \multirow{2}{*}{\multicolumn{6}{|c|}{$\begin{array}{l}\text { Included } \\
\text { Included }\end{array}$}} \\
\hline Industry Fixed Effects & & & & & & \\
\hline Observations & 9,101 & 12,306 & 9,303 & 12,434 & 9,283 & 12,405 \\
\hline Adjusted R²(\%) & 20.48 & 22.35 & 8.51 & 10.53 & 14.01 & 19.72 \\
\hline
\end{tabular}


Notes: This table presents the results from OLS regressions of insider trading profits on proprietary costs conducted at the insider-purchase date level. Standard errors are clustered by firm and year. ***, **, and * represent statistical significance at $p<0.01, p<0.05$, and $p<0.10$ (two-tailed), respectively. The sample covers the period 1986 to 2017 . Panel A reports insider trading profits for all insider purchases. Panel B reports insider trading profits for opportunistic purchases in Columns (1), (3), and (5) and routine purchases in Columns (2), (4), and (6). Insider trading profits are estimated over the 360 calendar days following the transaction date using daily alpha (Alpha) the intercept from Carhart's (1997) four-factor model, buy-and-hold abnormal stock returns (BHAR) using Carhart's (1997) four-factor model, and buy-and-hold raw stock returns (BHRaw). Insider purchases are classified as opportunistic or routine based on insiders' trading patterns in the three preceding years. If an insider trades in the same calendar month in three consecutive years, then all subsequent trades by this insider are classified as routine. If an insider trades in three consecutive years but no trades are made in the same calendar month, then all subsequent trades by this insider are classified as opportunistic. Composite is a composite measure of proprietary costs, defined as the sum of the values of $R \& D$, Patents, and Product Similarity, where each measure is standardized to have zero mean and unit variance. BHRaw, Turnover, and Volatility are measured over the period [-380, -20] before each trade, where day 0 is the transaction date. See Appendix A for additional variable definitions. All continuous variables are winsorized at $1 \%$ and $99 \%$. 


\section{Table 5 \\ Insider Purchases before Product Launches}

\begin{tabular}{|c|c|c|c|c|c|}
\hline \multirow{4}{*}{ Variable } & \multicolumn{5}{|c|}{$\begin{array}{l}\text { Coefficient } \\
(t \text {-statistic) }\end{array}$} \\
\hline & \multicolumn{2}{|c|}{ All } & \multicolumn{2}{|c|}{ Proprietary Periods } & \multirow{2}{*}{$\begin{array}{c}\text { Non-Proprietary } \\
\text { Periods } \\
\end{array}$} \\
\hline & {$[t+1 ; t+2]$} & $t+1$ & {$[t+1 ; t+2]$} & $t+1$ & \\
\hline & $(1)$ & $(2)$ & (3) & $(4)$ & $(5)$ \\
\hline Prop Period & $\begin{array}{l}-0.140 * * * \\
(-4.40)\end{array}$ & $\begin{array}{l}-0.083 * * * \\
(-2.59)\end{array}$ & & & \\
\hline Composite & & & $\begin{array}{l}-0.118 * * * \\
(-10.35)\end{array}$ & $\begin{array}{l}-0.044 * * * \\
(-4.05)\end{array}$ & $\begin{array}{l}-0.055 \\
(-0.72)\end{array}$ \\
\hline Size & $\begin{array}{l}-0.480 * * * \\
(-77.85)\end{array}$ & $\begin{array}{l}-0.513 * * * \\
(-76.89)\end{array}$ & $\begin{array}{l}-0.127 * * * \\
(-18.47)\end{array}$ & $\begin{array}{l}-0.205 * * * \\
(-47.11)\end{array}$ & $\begin{array}{l}-0.502 * * * \\
(-5.75)\end{array}$ \\
\hline$B M$ & $\begin{array}{l}-0.049 \\
(-1.43)\end{array}$ & $\begin{array}{l}-0.035 \\
(-1.01)\end{array}$ & $\begin{array}{l}0.323 * * * \\
(8.22)\end{array}$ & $\begin{array}{l}0.905 * * * \\
(28.58)\end{array}$ & $\begin{array}{l}-0.237 * \\
(-1.73)\end{array}$ \\
\hline BHRaw & $\begin{array}{l}-0.418 * * * \\
(-27.40)\end{array}$ & $\begin{array}{l}-0.354 * * * \\
(-21.48)\end{array}$ & $\begin{array}{l}-0.113 * * * \\
(-5.26)\end{array}$ & $\begin{array}{l}-0.358 * * * \\
(-15.54)\end{array}$ & $\begin{array}{l}-0.344 * \\
(-1.70)\end{array}$ \\
\hline Coverage & $\begin{array}{l}-0.024 \\
(-1.60)\end{array}$ & $\begin{array}{l}0.005 \\
(0.31)\end{array}$ & $\begin{array}{l}-0.183 * * * \\
(-9.28)\end{array}$ & $\begin{array}{l}-0.098 * * * \\
(-5.11)\end{array}$ & $\begin{array}{l}0.017 \\
(0.13)\end{array}$ \\
\hline InstOwn & $\begin{array}{l}-0.501 * * * \\
(-9.77)\end{array}$ & $\begin{array}{l}-0.467 * * * \\
(-8.53)\end{array}$ & $\begin{array}{l}-1.089 * * * \\
(-14.99)\end{array}$ & $\begin{array}{l}-1.192 * * * \\
(-23.00)\end{array}$ & $\begin{array}{l}-0.565 \\
(-1.31)\end{array}$ \\
\hline Turnover & $\begin{array}{l}0.024 * * \\
(1.98)\end{array}$ & $\begin{array}{l}0.033 * * \\
(2.49)\end{array}$ & $\begin{array}{l}-0.056 * * * \\
(-3.02)\end{array}$ & $\begin{array}{l}-0.026 \\
(-1.43)\end{array}$ & $\begin{array}{l}0.010 \\
(0.06)\end{array}$ \\
\hline Litigation & $\begin{array}{l}0.019 \\
(0.29)\end{array}$ & $\begin{array}{l}-0.162 * * \\
(-2.34)\end{array}$ & $\begin{array}{l}0.718 * * * \\
(10.00)\end{array}$ & $\begin{array}{l}1.428 * * * \\
(29.60)\end{array}$ & $\begin{array}{l}-0.394 \\
(-1.20)\end{array}$ \\
\hline Volatility & $\begin{array}{l}10.835 * * * \\
(10.56)\end{array}$ & $\begin{array}{l}6.347 * * * \\
(5.87)\end{array}$ & $\begin{array}{l}8.735 * * * \\
(6.71)\end{array}$ & $\begin{array}{l}-17.941 * * * \\
(-22.66)\end{array}$ & $\begin{array}{r}11.007 \\
(1.43)\end{array}$ \\
\hline Year Fixed Effects & & & Included & & \\
\hline Industry Fixed Effects & & & Included & & \\
\hline Observations & 7,666 & 5,742 & 1,410 & 761 & 4,102 \\
\hline Pseudo R $2(\%)$ & 6.60 & 6.61 & 6.65 & 8.42 & 5.56 \\
\hline
\end{tabular}

Notes: This table presents the results from tobit regressions of insider purchases on proprietary periods before product launches in Columns (1) and (2) and insider purchases on proprietary costs during (outside of) proprietary periods before product launches in Columns (3) and (4) (Column (5)). Standard errors are clustered by firm and year. ***, $* *$, and * represent statistical significance at $p<0.01, p<0.05$, and $p<0.10$ (two-tailed), respectively. The sample covers the period 2002 to 2017. The dependent variable is Purchases, the number of shares purchased by insiders during the year scaled by total number of shares outstanding at the beginning of the year. Prop Period is an indicator variable equal to one if the firm-year is in a proprietary period, zero otherwise. Proprietary periods are firm-year observations that have at least one product announcement in the subsequent two years $([t+1 ; t+2])$ but no announcement in the current year $(t)$ in Columns (1) and (3), or one product announcement in the subsequent year $(t+1)$ but no announcement in the current year $(t)$ in Columns (2) and (4). Composite is a composite measure of proprietary costs, defined as the sum of the values of $R \& D$, Patents, and Product Similarity, where each measure is standardized to have zero mean and unit variance. See Appendix A for additional variable definitions. All continuous variables are winsorized at $1 \%$ and $99 \%$. 


\section{Table 6 \\ Insider Purchases Following Reductions of Import Tariff Rates}

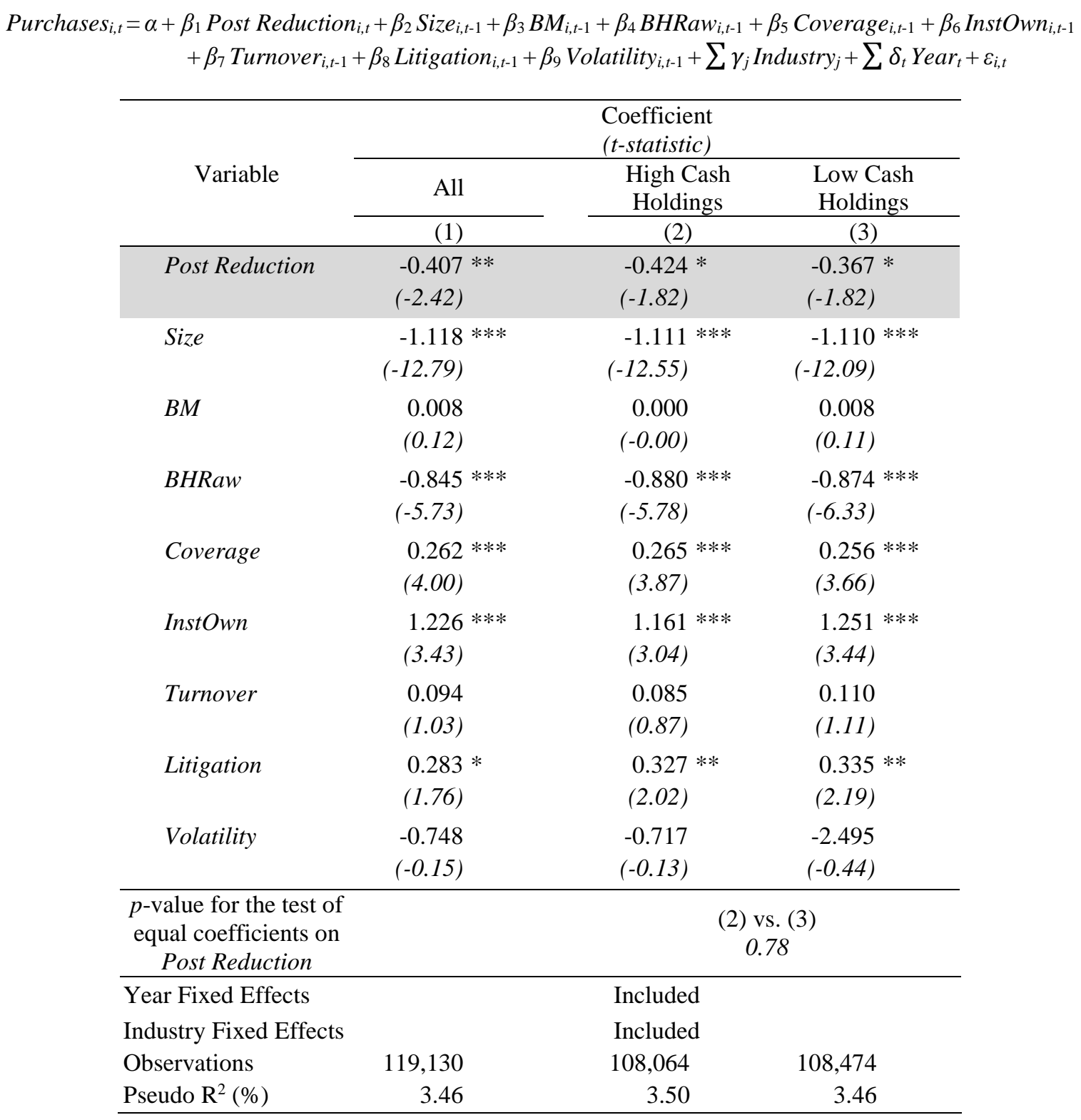

Notes: This table presents the results from a tobit regression of insider purchases on tariff rate reductions. Standard errors are clustered by industry and year. ${ }^{* * *}, * *$, and $*$ represent statistical significance at $p<0.01, p<0.05$, and $p$ $<0.10$ (two-tailed), respectively. The sample covers calendar years 1990 to 2017. The dependent variable is Purchases, the number of shares traded purchased by insiders during the year scaled by total number of shares outstanding at the beginning of the year. Post Reduction is an indicator variable equal to one if the industry experiences a tariff rate reduction by year $t-1$ that is larger than three times the median tariff rate reduction in that industry, zero otherwise. Columns (2) and (3) report results with affected firm-year observations classified as high and low cash holdings, respectively, where high (low) cash holdings firms are firms above (below) the median industry cash holdings in the year prior to the tariff reduction. Industry grouping is defined based on the three-digit SIC classification. See Appendix A for additional variable definitions. All continuous variables are winsorized at 1\% and $99 \%$. 
Table 7

Proprietary Costs and Insider Purchases, by Informativeness of Insider Trading

Purchases $_{i, t}=\alpha+\beta_{1}$ Composite $_{i, t-1}+\beta_{2}$ Size $_{i, t-1}+\beta_{3}$ BM $_{i, t-1}+\beta_{4}$ BHRaw $_{i, t-1}+\beta_{5}$ Coverage $_{i, t-1}+\beta_{6}$ InstOwn $_{i, t-1}$ $+\beta_{7}$ Turnover $_{i, t-1}+\beta_{8}$ Litigation $_{i, t-1}+\beta_{9}$ Volatility $_{i, t-1}+\sum \gamma_{j}$ Industry $_{j}+\sum \delta_{t}$ Year $_{t}+\varepsilon_{i, t}$

\begin{tabular}{|c|c|c|c|c|c|c|c|c|}
\hline \multirow{3}{*}{ Variable } & \multicolumn{8}{|c|}{$\begin{array}{l}\text { Coefficient } \\
(t \text {-statistic })\end{array}$} \\
\hline & Top 5 & Non-Top 5 & $\begin{array}{c}\text { Low } \\
\text { Complexity }\end{array}$ & $\begin{array}{c}\text { High } \\
\text { Complexity }\end{array}$ & $\begin{array}{l}\text { Small } \\
\text { Firms }\end{array}$ & $\begin{array}{l}\text { Large } \\
\text { Firms }\end{array}$ & $\begin{array}{c}\text { High Media } \\
\text { Coverage }\end{array}$ & $\begin{array}{c}\text { Low Media } \\
\text { Coverage }\end{array}$ \\
\hline & $(1)$ & $(2)$ & (3) & (4) & $(5)$ & $(6)$ & $(7)$ & $(8)$ \\
\hline Composite & $\begin{array}{l}-0.157 * * * \\
(-3.52)\end{array}$ & $\begin{array}{l}0.044 \\
(1.07)\end{array}$ & $\begin{array}{l}-0.307 * * * \\
(-3.39)\end{array}$ & $\begin{array}{l}-0.089 * \\
(-1.93)\end{array}$ & $\begin{array}{l}-0.231 * * * \\
(-3.14)\end{array}$ & $\begin{array}{l}-0.075 * * \\
(-2.56)\end{array}$ & $\begin{array}{l}-0.179 * * * \\
(-3.34)\end{array}$ & $\begin{array}{l}-0.081 * * \\
(-2.02)\end{array}$ \\
\hline $\begin{array}{c}p \text {-value for the test of } \\
\text { equal coefficients on } \\
\text { Composite }\end{array}$ & \multicolumn{2}{|c|}{$\begin{array}{l}\text { (1) vs. (2) } \\
<0.01\end{array}$} & \multicolumn{2}{|c|}{$\begin{array}{l}\text { (3) vs. (4) } \\
<0.01\end{array}$} & \multicolumn{2}{|c|}{$\begin{array}{l}\text { (5) vs. (6) } \\
0.01\end{array}$} & \multicolumn{2}{|c|}{$\begin{array}{l}\text { (7) vs. (8) } \\
0.08\end{array}$} \\
\hline $\begin{array}{l}\text { Control Variables } \\
\text { Year Fixed Effects } \\
\text { Industry Fixed Effects }\end{array}$ & \multicolumn{8}{|c|}{$\begin{array}{l}\text { Included } \\
\text { Included }\end{array}$} \\
\hline $\begin{array}{l}\text { Observations } \\
\text { Pseudo } \mathrm{R}^{2}(\%)\end{array}$ & $\begin{array}{r}63,416 \\
2.72\end{array}$ & $\begin{array}{r}63,416 \\
1.25\end{array}$ & $\begin{array}{r}20,994 \\
2.07\end{array}$ & $\begin{array}{r}42,422 \\
3.15\end{array}$ & $\begin{array}{r}31,887 \\
1.45\end{array}$ & $\begin{array}{r}31,529 \\
3.86\end{array}$ & $\begin{array}{r}12,047 \\
5.06\end{array}$ & $\begin{array}{r}21,619 \\
3.04\end{array}$ \\
\hline
\end{tabular}

Notes: This table presents the results from tobit regressions of insider purchases on proprietary costs. Standard errors are clustered by firm and year. $* * *, * *$, and * represent statistical significance at $p<0.01, p<0.05$, and $p<0.10$ (two-tailed), respectively. The sample covers the period 1986 to 2017 . The dependent variable is Purchases, the number of shares purchased by insiders during the year scaled by total number of shares outstanding at the beginning of the year. Columns (1) and (2) report results for insiders classified as top 5 and non-top 5 officers and directors, respectively. Columns (3) and (4) report results for firm-year observations classified as low and high complexity, respectively, where low (high) complexity firms are firms with single (multiple) business or geographic segments for the year. Columns (5) and (6) report results for firms classified as small and large firms, respectively, where small (large) firms are firms below (above) the median industry market value of equity at the beginning of the year. Columns (7) and (8) report results for firms classified as high and low media coverage, respectively, where high (low) media coverage firms are firms above (below) the median industry news coverage in the same size decile in the prior year. Industry grouping is defined based on the Fama-French (1997) 48-industry classification. Composite is a composite measure of proprietary costs, defined as the sum of the values of $R \& D$, Patents, and Product Similarity, where each measure is standardized to have zero mean and unit variance. See Appendix A for additional variable definitions. All continuous variables are winsorized at $1 \%$ and $99 \%$. 


\section{Table 8 \\ Proprietary Costs and Mechanisms Underlying Insider Purchases}

\section{Panel A: Insider Trading Restrictions}

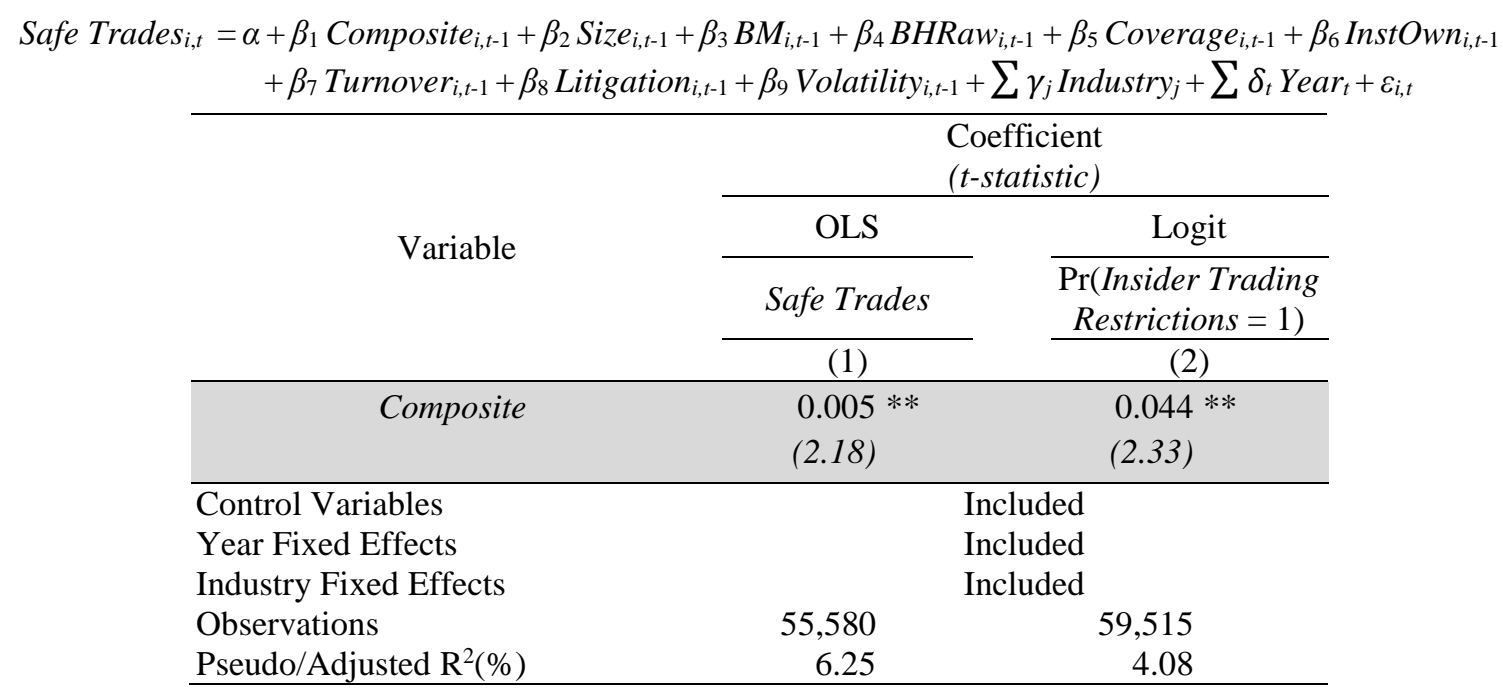

Panel B: Incentive Alignment - High versus Low Ownership

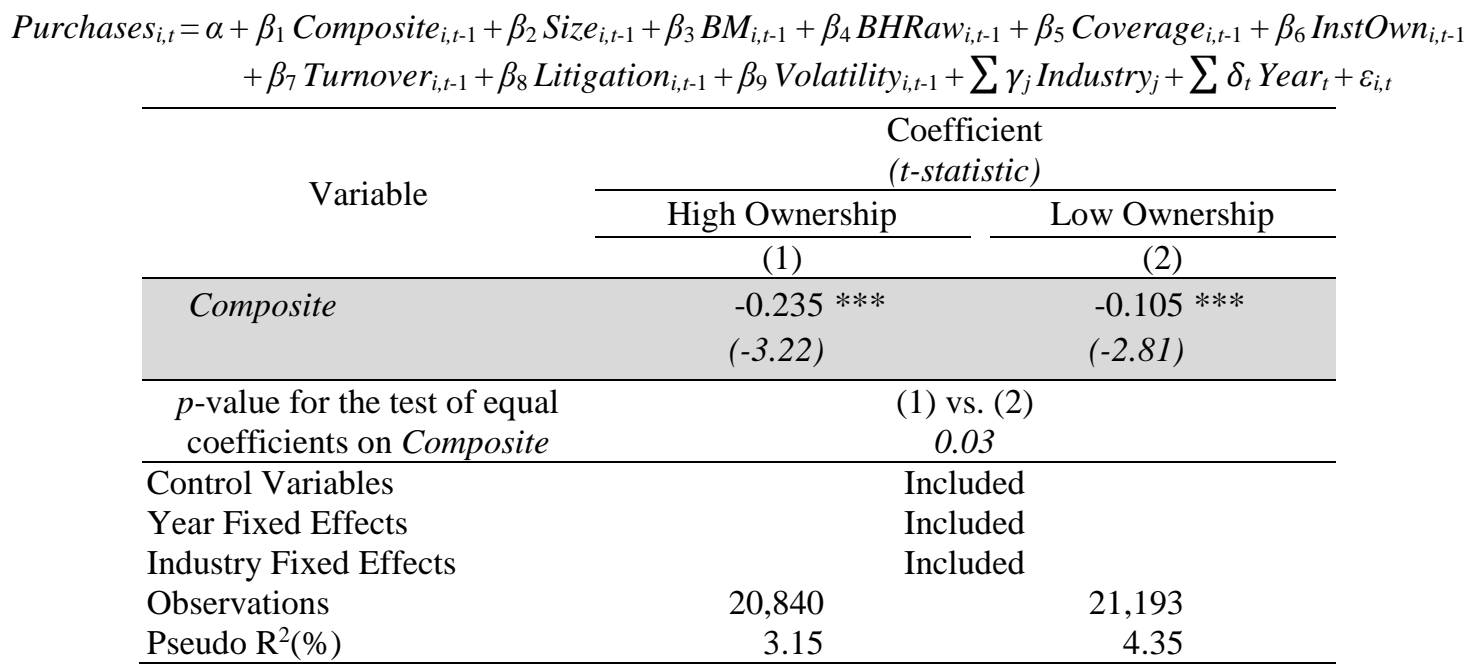

Notes: Panel A of this table presents the results from an OLS regression (Column (1)) of the percentage of safe trades on proprietary costs and a logistic regression (Column (2)) of the likelihood of imposing insider trading restrictions on proprietary costs. Panel B of this table presents the results from tobit regressions of insider purchases on proprietary costs. Standard errors are clustered by firm and year. $t$-statistics are reported in parenthesis. $* * *, * *$, and * represent statistical significance at $p<0.01, p<0.05$, and $p<0.10$ (two-tailed), respectively. The sample covers the period 1986 to 2017. In Panel A, Column (1), the dependent variable is the percentage of safe trades using three-year rolling windows, where safe trades are insider trades made within a month following quarterly earnings announcements. In Column (2), the dependent variable is an indicator variable equal to one if the firm imposes insider trading restrictions, zero otherwise, inferred from the beginning of a three-year rolling window if the percentage of safe trades is greater than or equal to $75 \%$ during the window. In Panel B, the dependent variable is Purchases, the number of shares purchased by insiders during the year scaled by total number of shares outstanding at the beginning of the year. Columns (1) and (2) report results for firm-year observations classified as high and low ownership, respectively, where low (high) ownership is based on the industry-year median share ownership held by top 5 executives. Composite is a composite measure of proprietary costs, defined as the sum of the values of $R \& D$, Patents, and Product Similarity, where each measure is standardized to have zero mean and unit variance. See Appendix A for additional variable definitions. All continuous variables are winsorized at $1 \%$ and $99 \%$. 